\title{
Implication of Potassium Channels in the Pathophysiology of Pulmonary Arterial Hypertension
}

\author{
Hélène Le Ribeuz $1,2,3$, Véronique Capuano ${ }^{1,2,3}$, Barbara Girerd 1,2,3, Marc Humbert 1,2,3, \\ David Montani ${ }^{1,2,3,+}$ and Fabrice Antigny $1,2,3, *,+(\mathbb{D}$ \\ 1 Faculté de Médecine, Université Paris-Saclay, 94270 Le Kremlin-Bicêtre, France; \\ helene.leribeuz@aol.com (H.L.R.); veronique.capuano@universite-paris-saclay.fr (V.C.); \\ barbara.girerd19@gmail.com (B.G.); mjc.humbert@gmail.com (M.H.); david.montani@aphp.fr (D.M.) \\ 2 INSERM UMR_S 999, Hypertension pulmonaire, Physiopathologie et Innovation Thérapeutique, \\ Hôpital Marie Lannelongue, 92350 Le Plessis-Robinson, France \\ 3 Assistance Publique-Hôpitaux de Paris (AP-HP), Service de Pneumologie et Soins Intensifs Respiratoires, \\ Centre de Référence de l'Hypertension Pulmonaire, Hôpital Bicêtre, 94270 Le Kremlin-Bicêtre, France \\ * Correspondence: fabrice.antigny@universite.paris-saclay.fr or antignyfabrice@gmail.com; \\ Tel.: +33-1-40-94-22-99 \\ $\dagger$ These authors contributed equally to the work.
}

Received: 30 June 2020; Accepted: 27 August 2020; Published: 1 September 2020

\begin{abstract}
Pulmonary arterial hypertension (PAH) is a rare and severe cardiopulmonary disease without curative treatments. PAH is a multifactorial disease that involves genetic predisposition, epigenetic factors, and environmental factors (drugs, toxins, viruses, hypoxia, and inflammation), which contribute to the initiation or development of irreversible remodeling of the pulmonary vessels. The recent identification of loss-of-function mutations in KCNK3 (KCNK3 or TASK-1) and ABCC8 (SUR1), or gain-of-function mutations in $A B C C 9$ (SUR2), as well as polymorphisms in KCNA5 (Kv1.5), which encode two potassium $\left(\mathrm{K}^{+}\right)$channels and two $\mathrm{K}^{+}$channel regulatory subunits, has revived the interest of ion channels in PAH. This review focuses on KCNK3, SUR1, SUR2, and Kv1.5 channels in pulmonary vasculature and discusses their pathophysiological contribution to and therapeutic potential in PAH.
\end{abstract}

Keywords: KCNK3; ABCC8; KCNA5; ABCC9; K2P3.1; SUR1; Kv1.5; SUR2

\section{Introduction}

Pulmonary arterial hypertension (PAH) is a rare and severe cardiopulmonary disease. PAH is a consequence of the progressive obstruction of distal pulmonary arteries $(<500 \mu \mathrm{m}$ in diameter). These modifications of the pulmonary vascular bed increase the right ventricular (RV) afterload, leading to RV hypertrophy and then RV failure and death [1]. PAH is defined by an elevation of the mean pulmonary arterial pressure $(\mathrm{mPAP})>25 \mathrm{mmHg}$, a pulmonary artery wedge pressure $\leq 15 \mathrm{mmHg}$, and a pulmonary vascular resistance (PVR) $\geq 3$ woods units [2]. PAH is still incurable, and lung transplantation is the only therapeutic option [3]. PAH may be idiopathic (iPAH, when the causes remain unknown), heritable (hPAH), induced by drugs, induced by toxins, or associated with other pathologies (connective tissue disease, HIV infection, portal hypertension, congenital heart disease, and schistosomiasis) [4]. 
The pathophysiology of PAH is complex and multifactorial. PAH is mostly caused by a dysfunction of pulmonary arterial endothelial cells (PAECs) and pulmonary arterial smooth muscle cells (PASMCs) characterized by abnormal pulmonary artery vasoconstriction and an unbalance between proliferation and apoptosis in favor of cell proliferation and apoptosis resistance [5]. PAEC dysfunction is characterized by an exaggerated production of vasoconstrictive and mitogen molecules, including endothelin-1 (ET-1), serotonin (5-HT), or thromboxane A2 (TXA) [6,7].

Most hPAH cases are due to a pathogenic mutation in the bone morphogenic protein receptor type II gene (BMPR2) (approximately 85\%) [8]. However, 17 other PAH-predisposing genes have recently been identified, including EIF2AK4, ACVRL1, TBX4, GDF2, SOX17, ENG, KCNK3, ABCC8, ATP13A3, SMAD9, AQP1, CAV1, BMP10, SMAD4, SMAD1, G6PD, and KDR [9-11]. Among all PAH-predisposing genes, two of them encode potassium $\left(\mathrm{K}^{+}\right)$channels or regulatory subunits of $\mathrm{K}^{+}$ channels, namely potassium channel subfamily K member 3 (KCNK3) and ATP-binding cassette subfamily $C$ member $8(A B C C 8)$, respectively. KCNK3 and $A B C C 8$ represent the only two channelopathies described in $\mathrm{PAH} . \mathrm{K}^{+}$channels are transmembrane proteins that are responsible for the circulation of $\mathrm{K}^{+}$ions according to the concentration gradient of $\mathrm{K}^{+}$from the cytoplasm $\left(\left[\mathrm{K}^{+}\right]=140 \mathrm{mM}\right)$ towards the extracellular medium $\left(\left[\mathrm{K}^{+}\right]=5 \mathrm{mM}\right) . \mathrm{K}^{+}$channels are categorized into three major groups based on their pharmacological and electrophysiological properties and structures: Inward-rectifying potassium channels (Kir), including ATP-sensitive potassium channels (KATP); voltage-gated potassium channels $(\mathrm{Kv})$; and two pore domain $\mathrm{K}^{+}$channels (K2P). $A B C C 8$ and $A B C C 9$ encode two different regulatory subunits of the Kir channel (KATP channels), KCNA5 encodes a Kv channel, and KCNK3 encodes a $\mathrm{K} 2 \mathrm{P}$ channel. $\mathrm{K}^{+}$channels are the most important regulator of the resting membrane potential (Em). The inhibition, downregulation, or loss-of-function (LOF) mutation in $\mathrm{K}^{+}$channels leads to plasma membrane depolarization of excitable and non-excitable cells. In excitable cells, Em depolarization activates voltage-gated $\mathrm{Ca}^{2+}$ channels, leading to an increase in the intracellular $\mathrm{Ca}^{2+}$ concentration $\left[\mathrm{Ca}^{2+}\right]_{i}[12,13]$. This increase of $\left[\mathrm{Ca}^{2+}\right]_{i}$ enhances PASMC constriction and proliferation [14], while the change in the intracellular $\mathrm{K}^{+}$concentration may modify the cell volume and apoptotic status of the cells [15]. This review focuses on PAH-predisposing genes that encode $\mathrm{K}^{+}$channels, their physiological functions in pulmonary vasculature and RV, their contributions to the pathophysiology of PAH, and their therapeutic potential in $\mathrm{PAH}$.

\subsection{KCNK3}

KCNK3, also called TASK-1 (TWIK-related acid sensitive $\mathrm{K}^{+}$) or K2P3.1, is a member of the K2P channel family. K2Ps are background $\mathrm{K}^{+}$conductance channels that contribute to resting membrane potentials. The K2P channels are composed of two subunits, each with two pore domains that together form a single pore highly selective for $\mathrm{K}^{+}$(Figure 1). The K2P family is comprised of 15 members and the following five subfamilies, which are classified according to their pharmacological and electrophysiological properties: TWIK, Tandem of $\mathrm{P}$ domains in Weak Inward rectifier $\mathrm{K}^{+}$ channel; TREK/TRAAK, TWIK-Related $\mathrm{K}^{+}$channel/TWIK-Related Arachidonic Acid-Stimulated $\mathrm{K}^{+}$ channel; THIK, Tandem pore domain Halothane-Inhibited $\mathrm{K}^{+}$channel; TALK, TWIK-related Alkaline pH-Activated $\mathrm{K}^{+}$channel; and TASK, TWIK-related Acid-Sensitive $\mathrm{K}^{+}$channel [13]. Gardener et al. demonstrated the expression of mRNA of TASK-1, TASK-2, THIK-1, TRAAK, and TREK-1 in rat pulmonary arteries, and confirmed the protein expression of TASK-1, TASK-2, TREK-1, and TWIK-2 [16]. $k c n k 6$-deficient mice develop spontaneous pulmonary hypertension $(\mathrm{PH})$ at between 8 and 20 weeks [17]. Nonetheless, we recently found that KCNK6 mRNA expression is unchanged in the pulmonary artery of iPAH patients [18]. 


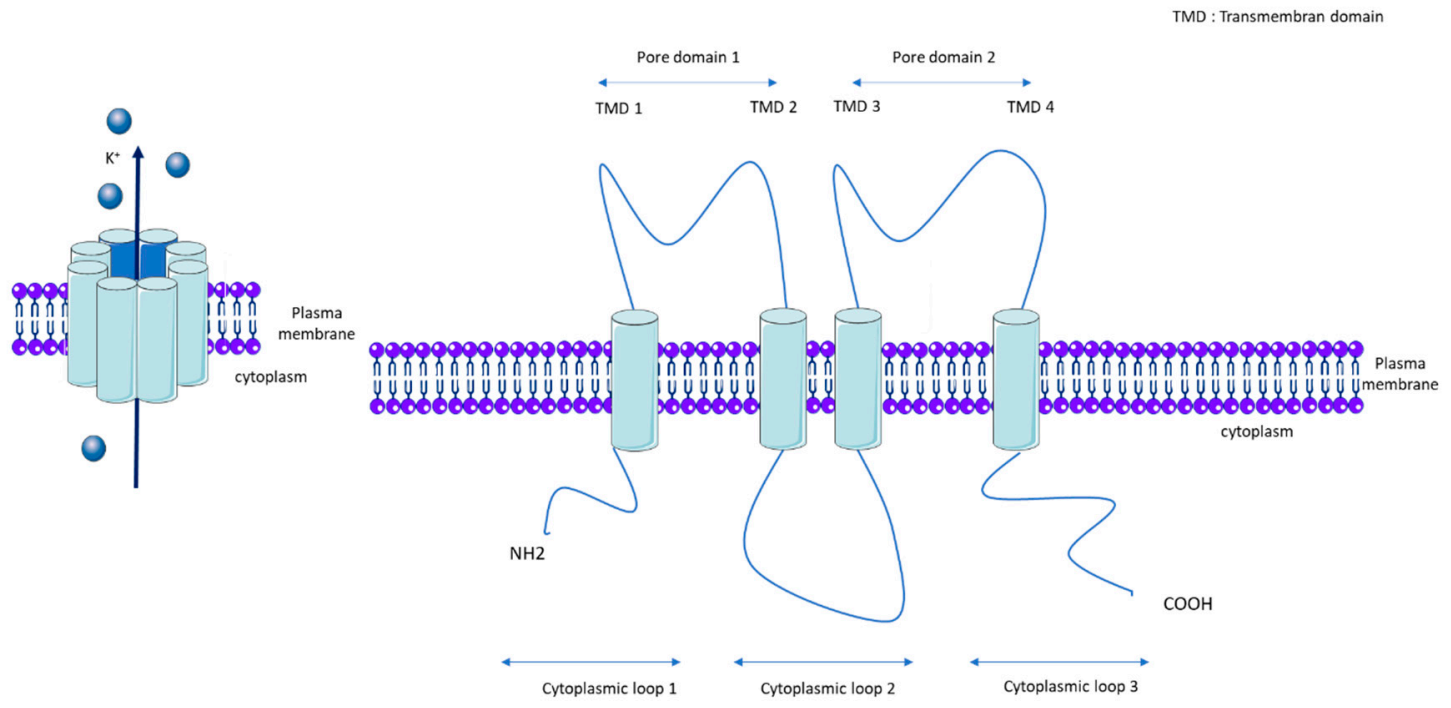

Figure 1. General molecular architecture of two pore potassium channels (K2P). TMD: Transmembrane domain.

\subsection{KCNK3 Properties and Regulatory Mechanisms}

KCNK3 can exist in a homodimer or heterodimer conformation, coupling with KCNK9 (TASK-3) [19]. However, KCNK9 (TASK-3) is not expressed in the lung [20]. The KCNK3 channel is inhibited by a wide range of molecules, including 4-aminopyridine. Contrary to other $\mathrm{K}^{+}$channels, the $\mathrm{KCNK} 3$ channel is insensitive to tetraethylammonium (TEA), glibenclamide, cesium, and intracellular $\left[\mathrm{Ca}^{2+}\right]_{\mathrm{i}}$.

KCNK3 is specifically blocked by a number of compounds, such as the aromatic carbonamide A293 developed by Sanofi. As demonstrated by Putzke et al., A293 at a $1 \mu \mathrm{M}$ concentration inhibited $75 \%$ of hKCNK3 and $50 \%$ of hKCNK9 currents, while other $\mathrm{K}^{+}$channels tested (TASK2, TASK4, TREK-1, Kv1.1, Kv1.3, Kv1.4, Kv1.5, Kv4.3, and hERG) were inhibited by less than 12\% [21].

Another KCNK3 inhibitor, the A1899 compound, as shown by Streit et al., when administered at $100 \mathrm{nM}$, inhibited $90 \%$ of hKCNK3 and $20 \%$ of KCNK9, while the functions of other $\mathrm{K}^{+}$channels tested (TASK-2, TASK-4, TREK-1, Kv1.1, Kv1.3, Kv1.5, Kv3.1, Kv4.3, HCN1, HCN2, Kir1.1, and Kir2.1) were inhibited by less than 11\% [22]. The commercial ML365 compound displays an IC50 $=16 \mathrm{nM}$ for hKCNK3, with more than a 60-fold selectivity for hKCNK3 over the hKCNK9 channel $[23,24]$.

The local anesthetics lidocaine and bupivacaine non-specifically inhibit KCNK3 at relatively high concentrations [25]. In addition, anandamide and methanandamide, doxapram, and PKTHPP are nonselective blockers of KCNK3 and KCNK9 [26-29].

To demonstrate the involvement of KCNK3 dysfunction in PAH in vivo, we chronically exposed control rats to the $\mathrm{A} 293$ compound $(2 \mathrm{mg} / \mathrm{kg} / \mathrm{d}$ ) and found that A293-exposed rats developed significant early signs of PH. Importantly, KCNK9 is not expressed in lungs from rats $[20,30]$ and thus cannot be part of the $\mathrm{K}^{+}$current. We were able to isolate $\mathrm{KCNK} 3$ from other outward- $\mathrm{K}^{+}$currents in vitro, using the KCNK3 blocker A293 [24,30]. KCNK3-specific inhibition points to a role of KCNK3 in cell proliferation in control human PASMCs [20].

$\mathrm{KCNK} 3$ is sensitive to extracellular $\mathrm{pH}$ variations. $\mathrm{KCNK} 3$ is $100 \%$ inhibited by $\mathrm{pH} 6.4,50-60 \%$ activated at a physiological pH (7.4), and fully activated by pH 8.4 [31]. Local inflammation can induce extracellular $\mathrm{pH}$ acidification. The exaggerated lung perivascular inflammation observed in PAH patients [32] could enhance perivascular acidification, partly mediating the loss of the KCNK3 function, and contribute to $\mathrm{PAH}$ pathogenesis by promoting pulmonary artery vasoconstriction and PASMC proliferation.

The KCNK3 channel function is reduced by hypoxia stimuli [33]. KCNK3 can mediate the initiation of hypoxia-induced depolarization in PASMCs, contributing to hypoxic pulmonary vasoconstriction. 
Endothelial cell dysfunction contributes to $\mathrm{PAH}$ pathogenesis by the overproduction of vasoconstrictive and angioproliferative molecules, such as endothelin-1 (ET-1) and serotonin (5-HT) [6,7]. KCNK3 is inhibited by the activation of Gq-protein coupled receptors (GqPCRs), including ET-1. Downstream GqPCR signaling, such as PKC, was suggested to mediate this inhibition. In addition, ET-1 can stimulate Rho-kinase to inhibit the KCNK3 function [34-36]. Therefore, the overproduction of ET-1 and 5-HT in PAH partly mediates the loss of the KCNK3 function, which contributes to PAH pathogenesis by promoting pulmonary artery vasoconstriction and PASMC proliferation. The activation of PLC via Gq proteins [37] inhibits KCNK3 via the diacylglycerol (DAG), PKC [38,39]. In addition, the KCNK3 function is enhanced by the protein kinase A (PKA)-dependent phosphorylation of KCNK3 [33], contributing to the vasorelaxing properties of prostanoids. The KCNK3 function is also activated by protein kinase G (PKG) [40], contributing to the vasorelaxating properties of PDE5 inhibitors or guanylate cyclase activators. Indeed, we recently found that Kcnk3-LOF-mutated rats are resistant to pulmonary artery relaxation mediated by sildenafil, which is a PDE5 inhibitor [20].

Moreover the inhibition of Src tyrosine kinase decreases the KCNK3 function [41], which can contribute to the pathogenesis of Dasatinib-(tyrosine kinase inhibitor)-induced PAH, since Dasatinib is known to inhibit Src tyrosine kinase [42]. The regulatory mechanisms of KCNK3 are summarized in Figure 2.

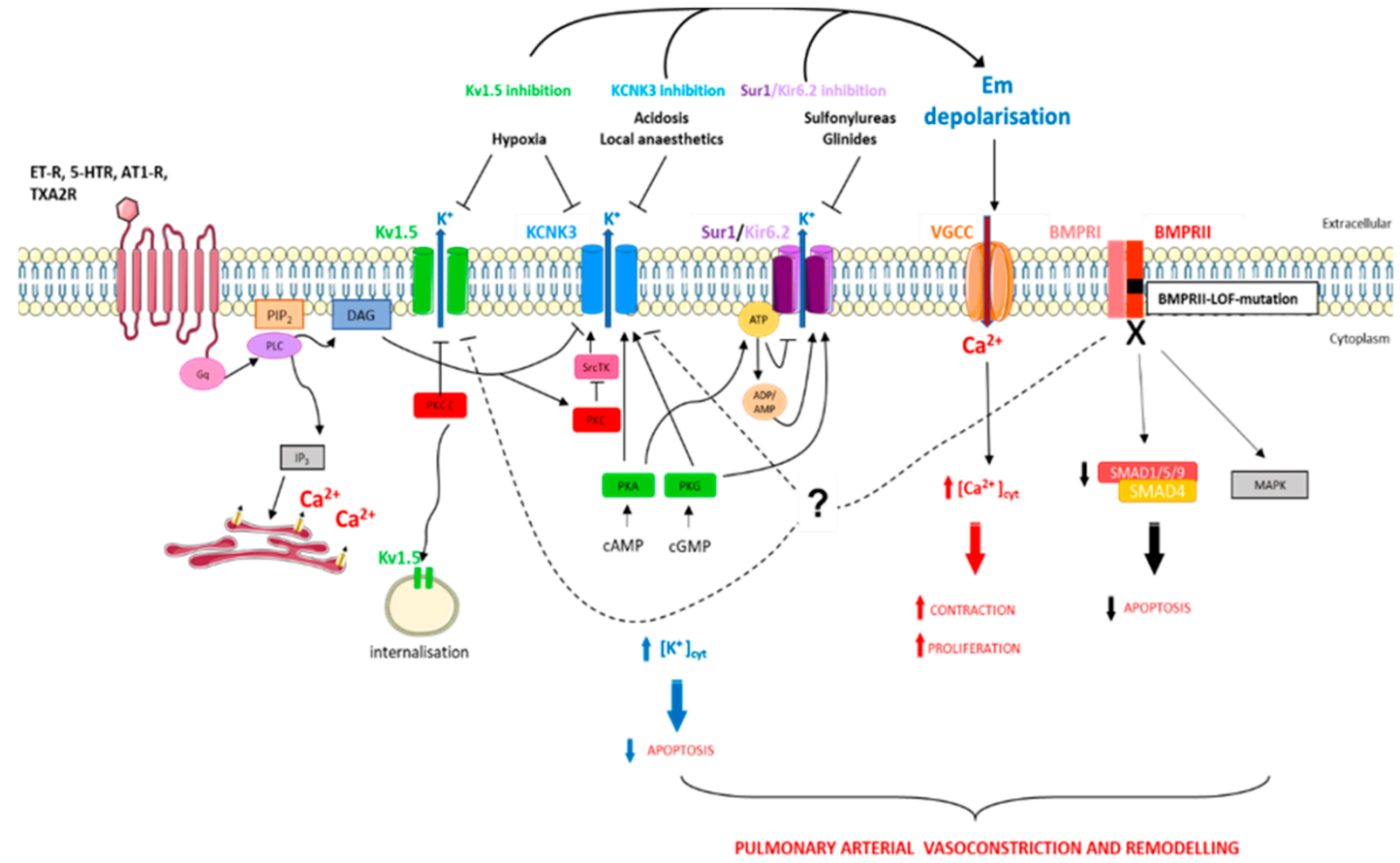

Figure 2. Schematic representation of pathways implicated in $\mathrm{K}^{+}$regulation in pulmonary artery smooth muscle cells in the context of pulmonary arterial hypertension (PAH). $\left[\mathrm{Ca}^{2+}\right]_{\text {cyt }}$, cytoplasmic calcium concentration; $\left[\mathrm{K}^{+}\right]_{\text {cyt }}$, cytoplasmic potassium concentration; 5 -HTR, serotonin receptor; AT1-R, angiotensin 1 receptor; BMPRI, BMP receptor type I; BMPRII, BMP receptor type II; cAMP, cyclic adenosine monophosphate; cGMP, cyclic guanosine monophosphate; DAG, diacylglycerol; Em, membrane resting potential; ET-R, endothelin receptor; IP3, inositol-1,4,5-triphosphate; MAPK, mitogen-activated protein kinases; PIP2, phosphatidylinositol-4,5-biphosphate; PKA, protein kinase A; PKC, protein kinase C; PKG, protein kinase G; PLC, phospholipase C; SMAD, mothers against decapentaplegic homologue; SrcTK, Src family tyrosine kinase; TXA2R, thromboxan A2 receptor. 


\subsection{KCNK3 Function and Expression in Pulmonary Vasculature and RV}

KCNK3 is expressed in several cell types, including heart cells, lung cells, PASMCs, and PAECs [13,43]. Patch-clamp recording has demonstrated that KCNK3 is functionally expressed in cultured human PASMCs $[30,33]$. The knockdown of KCNK3 in human PASMCs or the pharmacological inhibition of KCNK3 in isolated rat PASMCs leads to the depolarization of PASMC Em, demonstrating that KCNK3 contributes to the Em of PASMCs [30,33]. Moreover, plasma membranes of freshly isolated PASMCs from Kcnk3-LOF-mutated rats are depolarized compared to PASMCs isolated from WT rats [20]. In association with PASMC depolarization, we found that Kcnk3 pharmacological inhibition or Kcnk3-LOF-mutation causes PA vasoconstriction in rats [19,29]. In contrast to humans and rats, KCNK3 is not functional in mouse PASMCs [44].

At the cardiac level, KCNK3 is expressed in atria, ventricular tissues, and heart-conducting tissues in humans, mice, and rats $[21,43,45]$. Through whole-cell patch-clamp recordings, we found that KCNK3 is functionally expressed in adult rat RV cardiomyocytes, contributing to RV cardiomyocyte excitability (Em and action potential repolarization) [20,46]. In humans, KCNK3 contributes to action potential repolarization and the resting membrane potential of atrial cardiomyocytes. KCNK3 is a key actor of atrial fibrillation [47]. Moreover, the knockdown of KCNK3 in human-induced pluripotent stem cell (iPSC)-derived cardiomyocytes results in a significant prolongation of action potential duration, suggesting that KCNK3 also contributes to action potential repolarization in human ventricular cardiomyocytes [48]. Importantly, patients who develop PH with atrial fibrillation have a higher mortality than $\mathrm{PH}$ patients without atrial fibrillation [49], suggesting that KCNK3-LOF mutations or KCNK3-dyfunction could also contribute to the clinical deterioration of $\mathrm{PH}$ favoring the occurrence of atrial fibrillation.

\subsection{KCNK3 Mutations in PAH}

In 2013, Ma et al. identified six heterozygous mutations in KCNK3 in families with hPAH and iPAH patients [50]. Four years later, two additional KCNK3 mutations were identified in a Spanish cohort of PAH patients. One of the mutations (p.Gly106Arg) in a homozygous state is associated with an early and aggressive form of PAH [51]. Best et al. identified two additional mutations [52], and one additional mutation has been identified in Chinese pediatric PAH patients [53]. In 2020, a new mutation in KCNK3 was identified in a Dutch national cohort of children with PAH [54].

To date, 12 different KCNK3 mutations have been identified in 19 patients [11,50-55].

PAH patients that carry KCNK3 mutations are younger at the time of diagnosis (median age of 28 years compared to 42 years for iPAH patients), and they have a higher mPAP (76 mmHg compared to $56.4 \mathrm{mmHg}$ in iPAH patients) [18,56]. As illustrated in Figure 3, one mutation is located on the first cytoplasmic loop, one on the second cytoplasmic loop, three on the first pore domain, six on the second pore domain, and one in the fourth transmembrane domain (Figure 3).

The consequence of the KCNK3 mutation for the KCNK3 channel function has been measured by whole-cell patch clamp experiments, in cells overexpressing each different KCNK3-mutated channel (Table 1). As indicated in Table 1, all eight analyzed mutations (T8K, G97R, G106R, E182K, Y192C, G203D, L214R, and V221L) lead to KCNK3 LOF (Table 1). To date, A114V, K145M, V206L, and A189T have not been evaluated [24,50,54,57]. In addition, the application of ONO-RS-082, which is a phospholipase A2 inhibitor previously shown to activate the KCNK3 channel [58], restores the function of T8K, E182K, and V221L to the same level as the non-mutated channel in basal conditions, while G203D, G106R, and L214R are insensitive to ONO-RS-082 [24,50]. For the V221L mutation, the $\mathrm{KCNK} 3$-current is only restored by ONO-RS-082 at extracellular $\mathrm{pH} 8.3$. 


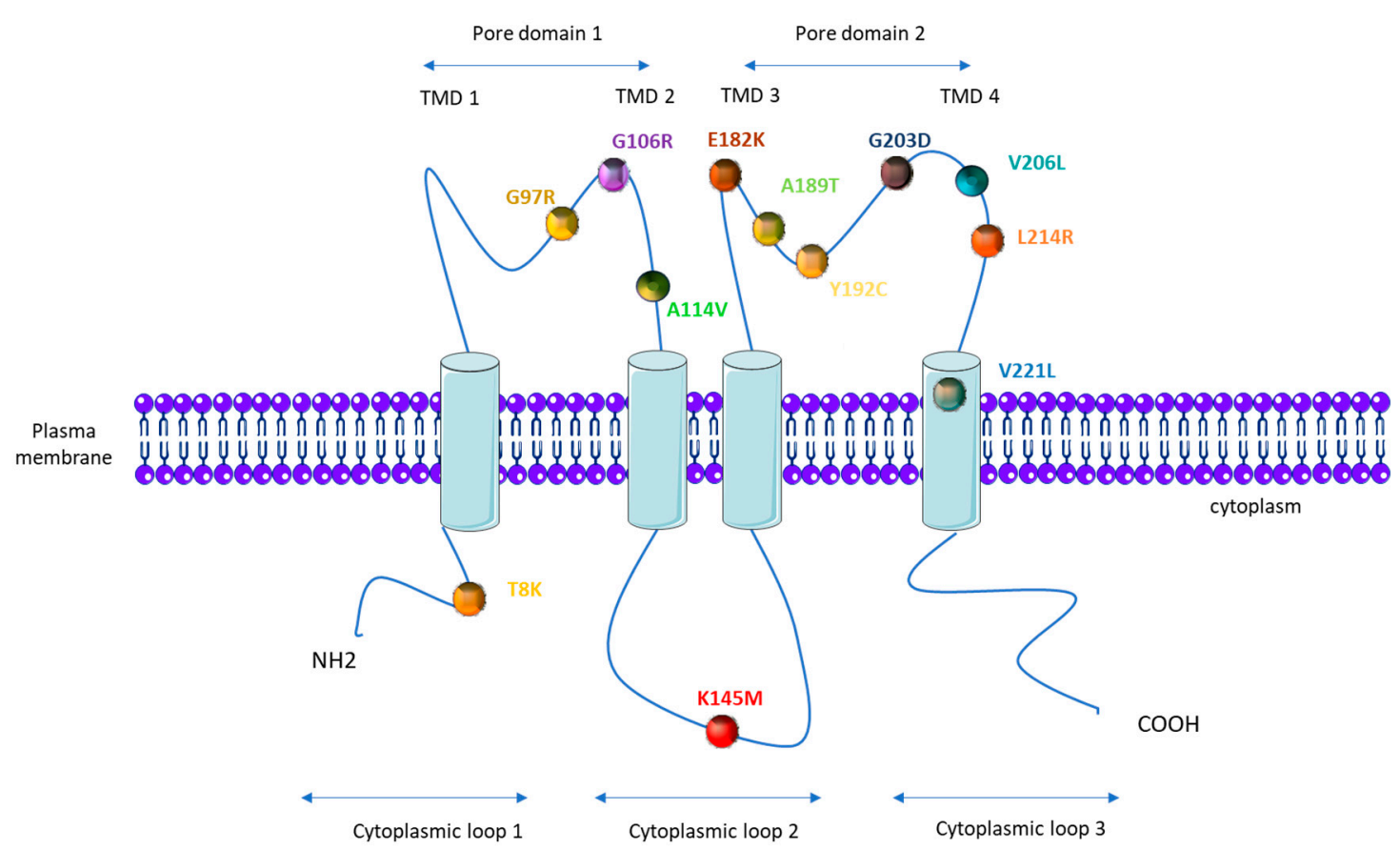

Figure 3. Topological analysis of the human KCNK3/TASK-1 channel. Positions indicate the mutations identified by Ma et al. [50], Navas et al. [51], Zhang [53], and Haarman [54].

Table 1. Potassium channel subfamily K member 3 (KCNK3) mutations identified in PAH patients and their consequences for the KCNK3/TASK-1 channel function.

\begin{tabular}{|c|c|c|c|c|c|c|c|}
\hline $\begin{array}{l}\text { KCNK3 } \\
\text { Mutation } \\
\text { (AA) }\end{array}$ & $\begin{array}{c}\text { KCNK3 } \\
\text { Mutation } \\
\text { (Nucleic } \\
\text { Acid) }\end{array}$ & $\begin{array}{l}\text { Number of } \\
\text { PAH Patients } \\
\text { Carrying the } \\
\text { Mutation }\end{array}$ & $\begin{array}{l}\text { Number } \\
\text { of Healthy } \\
\text { Carrier }\end{array}$ & Zygosity & $\begin{array}{l}\text { Function } \\
\text { (Patch } \\
\text { Clamp) }\end{array}$ & $\begin{array}{c}\text { Function } \\
\text { Restored by } \\
\text { ONO-RS-082 }\end{array}$ & References \\
\hline T8K & & 1 & & Heterozygous & loss & yes & [50] \\
\hline G97R & $289 \mathrm{G}>\mathrm{A}$ & 2 & 1 & Heterozygous & loss & / & [50] \\
\hline G106R & $316 \mathrm{G}>\mathrm{C}$ & 2 & 1 & $\begin{array}{l}\text { Heterozygous and } \\
\text { homozygous }\end{array}$ & loss & no & [51] \\
\hline A114V & $341 \mathrm{C}>\mathrm{T}$ & 1 & & Heterozygous & 1 & 1 & [53] \\
\hline K145M & $434 \mathrm{~A}>\mathrm{T}$ & 1 & & Heterozygous & 1 & 1 & [52] \\
\hline E182K & & 1 & & Heterozygous & loss & yes & [50] \\
\hline A189T & $565 \mathrm{G}>\mathrm{A}$ & 1 & & Heterozygous & 1 & 1 & [52] \\
\hline Y192C & & 1 & & Heterozygous & loss & 1 & [50] \\
\hline G203D & $608 \mathrm{G}>\mathrm{A}$ & 6 & 1 & Heterozygous & loss & no & {$[50,55]$} \\
\hline V206L & $616 \mathrm{G}>\mathrm{T}$ & 1 & & Heterozygous & 1 & 1 & [54] \\
\hline L214R & $641 \mathrm{~T}>\mathrm{G}$ & 1 & & Heterozygous & loss & no & [51] \\
\hline V221L & $661 \mathrm{G}>\mathrm{C}$ & 1 & & Heterozygous & loss & 1 & [50] \\
\hline
\end{tabular}

\subsection{Consequences of KCNK3 Dysfunction for the Physiopathology of PAH}

Since the discovery of KCNK3 mutations in PAH patients, we have found that KCNK3 expression is reduced in lung and pulmonary arteries from $\mathrm{PAAH}$ and hPAH patients and that the KCNK3 function is reduced in hPASMCs from iPAH patients. We have also found that KCNK3 expression and function are progressively lost in PASMCs and PAECs isolated from the MCT-PH rat model [30]. Moreover, after the chronic in vivo pharmacological inhibition of KCNK3, we observed an aberrant increase in pulmonary vascular cell proliferation and a significant increase in the right ventricular systolic pressure (RVSP) [30]. In association with the fact that KCNK3 is not functional in mouse PASMCs, Manoury et al. showed that $k c n k 3^{-/}$mice do not develop altered PA vasoreactivity [44]. Finally, $k c n k 3^{-/-}$ 
mice develop similar pulmonary hypertension (PH) after chronic hypoxia exposure to WT mice [59]. Recently, unpublished results have indicated that after chronic exposure to lipopolysaccharide (an inflammatory stressor), $k c n k 3^{-/}$mice develop more severe PH than WT mice, which is associated with a more pronounced infiltration of inflammatory cells [60].

Using the first Kcnk3-LOF-mutant rats generated by CRISPR/Cas9, Lambert et al. demonstrated that Kcnk3-LOF-mutant rats develop a spontaneous elevation of RVSP and pulmonary ventricular resistance that is associated with pulmonary vessel neomuscularization. At the molecular level, we found that lungs from Kcnk3-LOF-mutant rats are characterized by an increase in proliferative signaling pathways, such as ERK1/2, SRC, and AKT. Hypoxia inducible factor- $1 \alpha(\mathrm{HIF}-1 \alpha)$ is also increased in Kcnk3-LOF-mutant rats. These dysregulations are commonly observed in hPASMCs and hPAECs of PAH patients [20]. In addition, after MCT or chronic hypoxia exposure, Kcnk3-LOF-mutant rats develop higher $\mathrm{PH}$ compared to WT rats.

Regarding the involvement of Kcnk3 dysfunction in the proliferative phenotype of PAH PASMC, we found that the knockdown of KCNK3 in control hPASMCs enhances hPASMC proliferation in correlation with an increase of HIF- $1 \alpha$ expression and over-phosphorylation of ERK1/2, which are hallmarks of proliferation/apoptosis imbalance and PAH development. Finally, tetramethylrhodamine ethyl ester (TMRE) experiments have indicated that PASMC mitochondria from Kcnk3-LOF-mutant rats or siKCNK3 hPASMCs are significantly depolarized and fragmented compared to the control condition [20]. Altogether, these results demonstrate that Kcnk3-LOF leads to several defects and dysregulation, thereby increasing the susceptibility to developing PAH. Additionally, using the whole-cell patch-clamp technique, we found that the KCNK3 current is strongly reduced in freshly isolated PASMCs from Bmpr2-LOF rats compared to WT PASMCs. In association with this decreased KCNK3 function, we observed a significant depolarization of the Em in PASMCs from Bmpr2-LOF rats [61].

Han et al. recently found that resistin-like molecule- $\beta$ (RELM- $\beta)$ lung protein expression is strongly increased in chronic hypoxia rats. Using hPASMCs, these authors found that RELM- $\beta$ promotes hPASMC proliferation by downregulating KCNK3 expression. Indeed, RELM- $\beta$ overexpression reduces KCNK3 expression and enhances hPASMC proliferation, while siRNA against RELM- $\beta$ increases KCNK3 expression and reduces hPASMC proliferation [62]. These results suggest that RELM- $\beta$ is a key player, modulating KCNK3 in PH induced by chronic hypoxia. Previously, Angelini et al. found that RELM- $\beta$ protein expression is strongly increased in scleroderma-associated PH lungs compared to a control, while RELM- $\beta$ expression is unchanged in the lungs of iPAH patients, highlighting that RELM- $\beta$ contributes to the development of scleroderma-associated PH [63]. The contribution of KCNK3 dysfunction in scleroderma-associated PH is unknown; however, we could hypothesize that RELM- $\beta$ overexpression should reduce KCNK3 expression in the lungs of scleroderma-associated $\mathrm{PH}$ patients. Further experiments are needed to investigate the contribution of KCNK3 in scleroderma-associated PH.

\section{ATP Binding Cassette Subfamily C Member 8 (ABCC8)}

$A B C C 8$ codes for sulfonylurea receptor 1 (SUR1), which is a member of the ATP binding cassette (ABC) family, comprised of a large group of membrane transporters [64]. SUR1 is a regulatory subunit of KATP channels.

KATP channels are inhibited by intracellular ATP $(100 \mu \mathrm{M}-10 \mathrm{mM})$ [65], and this inhibition is mediated by the coupling of $\mathrm{Mg}^{2+}$ with ATP [66]. KATP forms a hetero-octameric conformation composed of four inward-rectifier- $\mathrm{K}^{+}$channel subunits (Kir6.x), which represent the pore forming subunits, and four regulatory subunits composed of Sur.x (sulphonylurea receptor) (Figure 3).

There are two types of Kir6.x subunits (Kir6.1 and Kir6.2) and two types of Sur.x subunits (SUR1 and SUR2), and there are two splice variants of SUR2 (SUR2A and SUR2B). The KATP subunit can co-assemble in different manners, depending on the tissue type. On human chromosome 11, $A B C C 8$ encodes SUR1 and KCNJ11 encodes Kir6.2. On human chromosome 12, ABCC9 encodes SUR2 and KCNJ8 encodes Kir6.1 [67]. 


\subsection{SUR1 Properties and Mechanisms of Regulation}

SUR1 is composed of three transmembrane domains (TMD0, TMD1, and TMD2), two nucleotide-binding domains (NBD1 and NBD2), and one cytoplasmic loop (Figure 4). The major role of SUR1 is as a regulator of the Kir6. $2 \mathrm{~K}^{+}$-channel. SUR1/Kir6.2 is regulated by the metabolic state of the cells as an increase of intracellular ATP leads to channel inhibition. ATP binds to the NBD domains of SUR1 and Kir6.2. Intracellular AMP stimulates the activation of KATP (SUR1/Kir6.2). The AMP/ATP ratio is a key regulator of KATP $[68,69]$.

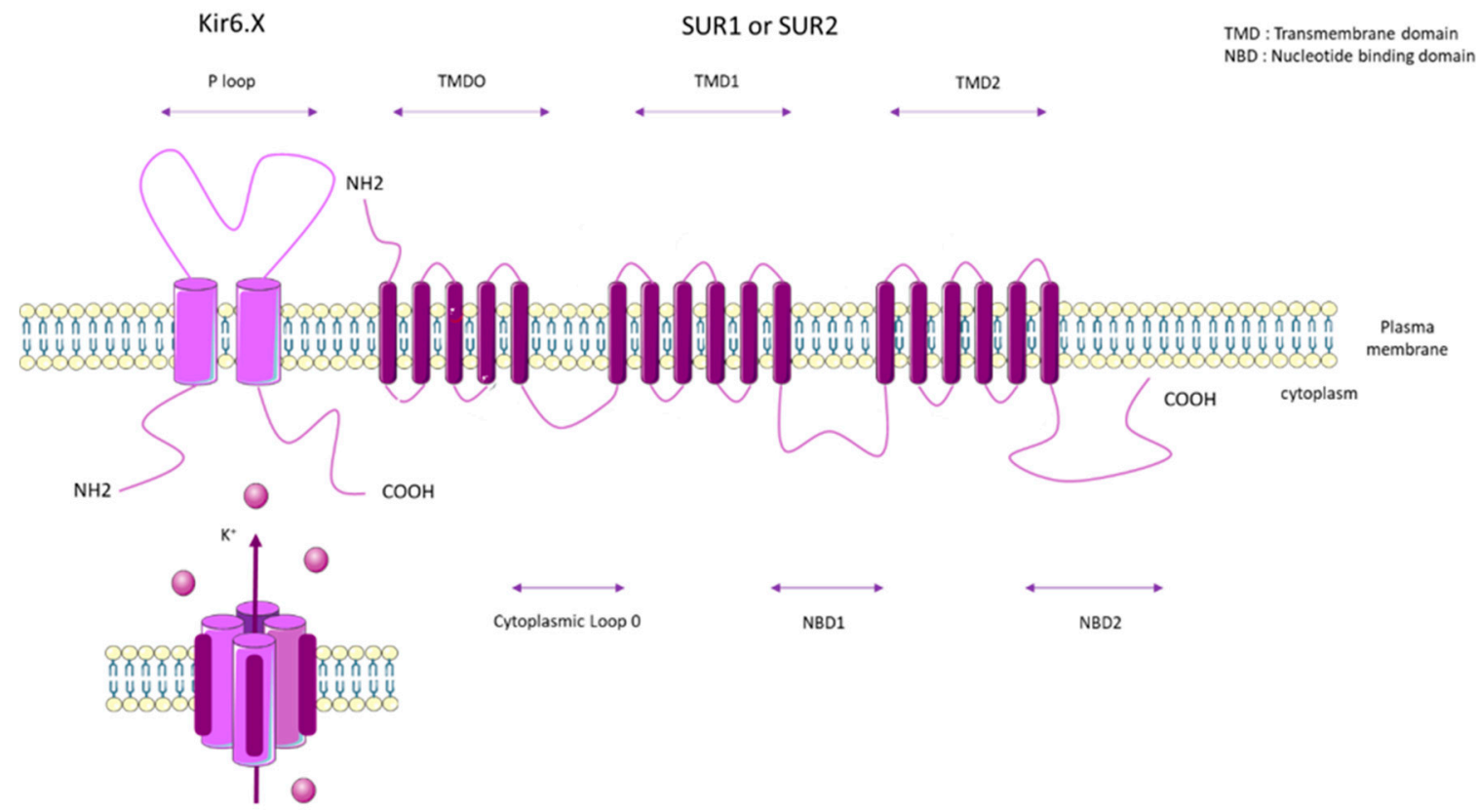

Figure 4. General molecular architecture of ATP-sensitive potassium channels (KATP) channels. The KATP form in a hetero-octameric conformation is composed of four inward-rectifier- $\mathrm{K}^{+}$channel subunits (Kir6.x), which represent the pore forming subunits, and four regulatory subunits (Sur.x, sulfonylurea receptor). There are two types of Kir 6.x subunits (Kir6.1 and Kir6.2) and two types of Sur.x subunits (SUR1 and SUR2), and there are two splice variants of SUR2 (SUR2A and SUR2B). KATP subunits co-assemble in different manners, depending on the tissue type. TMD: Transmembrane domain. NBD: Nucleotide binding domain.

SUR1 is modulated by the following two classes of drugs: (1) Sulfonylureas, which inhibit KATP opening, that bind to the NBD loop (glibenclamide, tolbutamide, and mitiglinide) [70], and (2) SUR1/Kir6.2, which is activated by $\mathrm{K}_{\text {ATP }}$ channel openers. SUR1 is highly activated by diazoxide, barely activated by pinacidil, and never activated by nicorandil [71]. Kir6.2 is activated by intra- and extracellular $\mathrm{Zn}^{2+}$ [72]. KATP channels are activated by ET-1, which acts as a vasodilator on vascular smooth muscle cells when mediated by H2S (an endothelial-derived factor) [73]. In HEK293 cells, PKC inhibits $\mathrm{K}_{\text {ATP }}$ [74]. Moreover, in rat mesenteric arterial smooth muscle cells, angiotensin II-mediated PKA and PKC inhibition leads to the closure and inhibition of $\mathrm{K}_{\text {ATP }}$ [75]. Similarly to KCNK3, KATP channels are known to be activated by PKA- and PKG-dependent phosphorylation [76], suggesting that KATP activation contributes to the vasorelaxating effects of prostanoids and PDE5 inhibitors or guanylate cyclase activators. The regulatory mechanisms of SUR1/Kir6.2 are summarized in Figure 2.

\subsection{SUR1 Function and Expression in Pulmonary Vasculature and RV}

SUR1 and Kir6.2 are mostly co-assembled together, and they are expressed in the brain [77], heart [78], and lung vascular tissues (PAECs and PASMCs) [79,80]. SUR1 also co-assembles and 
regulates transient receptor melatonin 4 (TRPM4), which is a non-selective cationic channel [81]. However, TRPM4 is expressed in PASMCs, supporting the hypothesis of SUR1/TRPM4 co-assembly in pulmonary vasculature [82]. In cerebral arteries, TRPM4 plays a critical role in the myogenic constriction of cerebral arteries by participating in Em [83]. By regulating the TRPM4 function, we hypothesized that $A B C C 8$-LOF also regulates the Em of PASMC and consequently contributes to vasoconstriction and pulmonary artery remodeling. SUR1 can also be associated with Kir6.1 [84,85].

In smooth muscle cells from pig coronary arteries, hypoxia exposure activates $\mathrm{K}_{\mathrm{ATP}}$ (glibenclamide $\mathrm{K}^{+}$-sensitive current) [86]. In femoral smooth muscle cells, $\mathrm{K}_{\mathrm{ATP}}$ is activated by anoxia, but not by hypoxia [87].

SUR1/Kir6.2 are expressed in the human heart, especially in the atria and ventricle [88], including RV tissues [80]. In mice, SUR1/Kir6.2 are mostly involved in atrial myocyte sarcolemmal KATP, whereas SUR2A/Kir6.2 generate ventricular KATP [88]. In humans and in larger animals, SUR1 contributes to sarcolemmal KATP in ventricular and atrial myocytes [89]. The opening of cardiac KATP channels reduces action potential repolarization and the refractory period [88].

\subsection{ABCC8 Mutations in PAH}

In 2018, whole-exome sequencing discovered 12 different heterozygous mutations in $A B C C 8$, which encodes SUR1, in PAH patients [79]. To date, 11 missense mutations and one splice variant have been identified in PAH patients.

PAH patients that carry the $A B C C 8$ mutation are younger at diagnosis (14 years compared to 42 years for iPAH patients), but have a similar mPAP to iPAH patients $(47.6 \mathrm{mmHg}$ for $A B C C 8$-mutated patients and $56.4 \mathrm{mmHg}$ for iPAH patients) [79]. These mutations are localized in amino acid residues well-conserved across species and localized at crucial regions in the protein (five in NBD loops 1 and 2, two in the cytoplasm loop, and four in the TMD0) (Figure 5).

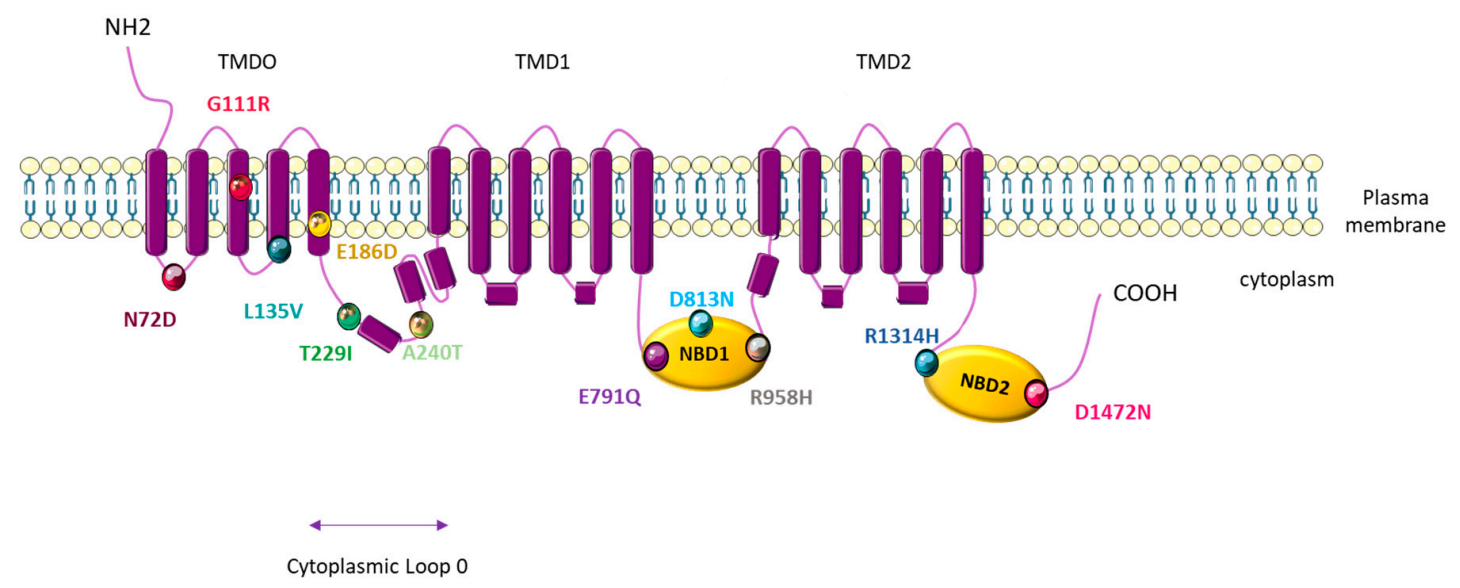

Figure 5. Topological analysis of the human ATP-binding cassette subfamily $C$ member 8 (ABCC8)/sulfonylurea receptor 1 (SUR1) channel. Positions indicate the mutations identified by Bohnen $\mathrm{M}$ et al. [79].

PAH patients with the $A B C C 8$ mutation generally do not carry other gene mutations, except for one patient, who has been shown to also carry a TBX4 mutation and develop PAH at an early stage ( $<1$ year). Four rare variants (p.G111R, p.L135V, p.D813N, and p.D1472N) have been described in congenital hyperinsulinism, and two other variants (p.T229I and p.R1314H) have been described in neonatal diabetes mellitus. However, these patients with rare variants did not develop one of the above described pathologies. It is well-known that diabetes induces endothelial dysfunction in systemic vessels and that diabetic patients have a higher risk of developing myocardial infarction and stroke. However, the effect of diabetes on the pulmonary circulation is unclear. Reza Movahed et al. 
demonstrated that patients with diabetes mellitus have a higher prevalence of pulmonary embolism and pulmonary hypertension [90]. Based on the REVEAL registry, diabetes is found to be a common comorbidity in US patients with PH [91]. Additionally, the long-term survival of diabetic PAH patients is worse than that of non-diabetic PAH patients [92].

By patch-clamp recordings and Rubidium $\left({ }^{86} \mathrm{Rb}^{+}\right)$efflux assays in cells overexpressing each different mutated-SUR1 + WT-Kir6.2, Bohnen et al. found that 11 out of 12 mutations led to a severe decrease in the SUR1/Kir6.2 current [79]. Through ${ }^{86} \mathrm{Rb}^{+}$assays in basal metabolic and inhibited metabolic conditions, these researchers measured a significant decrease in SUR1/Kir6.2 activity for three SUR1 mutants in basal conditions (A240T, D813N, and D1472N) and a significant decrease in SUR1/Kir6.2 activity in inhibited metabolic conditions for five mutations (L135V, A240T, D813N, R958H, and D1472N). Altogether (patch-clamp and Rb assays), these results indicate a significant decrease in the basal or maximal channel activity for all SUR1 mutants tested. Importantly, the function of L135V, E186D, A240T, E791Q, D813N, R958H, R1314H, and D1472N is restored in the presence of diazoxide $(100 \mu \mathrm{M})$ (Table 2) [79].

Table 2. ABCC8 mutations identified in PAH patients and their consequences for the Sur1/Kir6.2 channel function.

\begin{tabular}{|c|c|c|c|c|c|c|}
\hline \multirow{2}{*}{$\begin{array}{c}A B C C 8 \\
\text { Mutation } \\
\text { (AA) }\end{array}$} & \multirow{2}{*}{$\begin{array}{c}A B C C 8 \\
\text { Mutation } \\
\text { (Nucleic } \\
\text { Acid) }\end{array}$} & \multirow{2}{*}{$\begin{array}{l}\text { Number of PAH } \\
\text { Patients Carrying } \\
\text { the Mutation }\end{array}$} & \multirow[b]{2}{*}{ Zygosity } & \multicolumn{2}{|c|}{ Function } & \multirow{2}{*}{$\begin{array}{c}\text { Function } \\
\text { Restored by } \\
\text { Diazoxide }\end{array}$} \\
\hline & & & & $\begin{array}{c}\text { (Patch } \\
\text { Clamp) }\end{array}$ & $\begin{array}{c}\text { (Rubidium } \\
\left(86 \mathrm{Rb}^{+}\right) \text {Efflux } \\
\text { Assays) }\end{array}$ & \\
\hline N72D & $214 \mathrm{~A}>\mathrm{G}$ & 1 & Heterozygous & 1 & I & I \\
\hline G111R & $331 \mathrm{G}>\mathrm{A}$ & 1 & Heterozygous & 1 & I & 1 \\
\hline L135V & $403 C>G$ & 1 & Heterozygous & loss & decrease & yes \\
\hline E186D & $558 \mathrm{G}>\mathrm{T}$ & 1 & Heterozygous & loss & not decrease & yes \\
\hline $\mathrm{T} 229 \mathrm{I}$ & $686 \mathrm{C}>\mathrm{T}$ & 1 & Heterozygous & 1 & I & I \\
\hline $\mathrm{A} 240 \mathrm{~T}$ & $718 \mathrm{G}>\mathrm{A}$ & 1 & Heterozygous & loss & decrease & yes \\
\hline E791Q & $2371 \mathrm{G}>\mathrm{C}$ & 1 & Heterozygous & loss & small decrease & yes \\
\hline $\mathrm{D} 813 \mathrm{~N}$ & $2437 \mathrm{G}>\mathrm{A}$ & 1 & Heterozygous & loss & decrease & yes \\
\hline $\mathrm{R} 958 \mathrm{H}$ & $2873 \mathrm{G}>\mathrm{A}$ & 1 & Heterozygous & not loss & decrease & yes \\
\hline $\mathrm{R} 1314 \mathrm{H}$ & $3941 \mathrm{G}>\mathrm{A}$ & 1 & Heterozygous & loss & small decrease & yes \\
\hline $\mathrm{D} 1472 \mathrm{~N}$ & $4414 \mathrm{G}>\mathrm{A}$ & 1 & Heterozygous & loss & decrease & yes \\
\hline 1 & $2694 \mathrm{~T}>2 \mathrm{G}$ & 1 & Heterozygous & I & I & I \\
\hline
\end{tabular}

Mutations in ABCC8 and KCNJ11 are the major cause of neonatal diabetes mellitus [93] and congenital hyperinsulinism [94]. These pathologies are generally treated with sulfonylurea therapy, which leads to a better regulation of insulin secretion and control of glycemia.

\subsection{Consequences of ABCC8 Dysfunction for the Physiopathology of PAH}

Currently, there are only a few studies on KATP channels in pulmonary circulation and their implication in $\mathrm{PH}$.

kcnj11-deficient mice were generated to study the implication of the KATP channel in pancreatic $\beta$-cells. Surprisingly, these mice do not develop the expected hyperglycemic phenotype [95]. kcnj11 ${ }^{-/-}$ mice do not have any obvious cardiovascular defects, but are more sensitive to exercise and stress [96].

$k_{c n j 11^{-/}}$mice submitted to left ventricular (LV) pressure overload induced by transverse aortic constriction (TAC) present an abnormal prolongation of the LV cardiomyocyte action potential and an increase in the LV diastolic pressure compared to WT TAC [97]. These results demonstrate a protective role of the KATP channel in hypertensive conditions. In another experimental model of hypertension induced by unilateral nephrectomy and mineralocorticoid salt challenge to mimic chronic 
hyperaldosteronism, $k c n j 11^{-/}$mice exhibit a reduced survival rate associated with a more rapid development of cardiac remodeling and heart failure compared to WT mice [98].

$a b c c 8^{-/-}$mice were generated to determine the role of KATP in insulin secretion. However, $a b c c 8^{-/-}$ mice do not have dysregulated insulin secretion $[99,100]$.

Recently, our preliminary results indicated that SUR1 and Kir6.2 expression levels are maintained in the lungs of $\mathrm{PAH}$ and hPAH patients and three different experimental $\mathrm{PH}$ rat models. Myograph experiments on isolated pulmonary arteries (PAs) from non-PAH patients and control rats suggest that SUR1/Kir6.2 are implicated in PA tone regulation as SUR1 activation induces PA relaxation and SUR1 inhibition predisposes to PA vasoconstriction. We also found that $A B C C 8$ mRNA expression is decreased in the RV from PAH patients and MCT-PH rats [80], but that KCNJ11 mRNA expression is unchanged in the RV from PAH patients. In addition, Kcnj11 mRNA expression is decreased in rat hearts and in H9c2 cells under hypoxia conditions [101].The reduction of ABCC8 expression in the RV from PAH patients and MCT-PH rats may contribute to abnormal PH-RV cardiomyocyte excitability, contractility, and metabolism [43].

\section{Other Genetic Alterations in Genes Coding for $\mathrm{K}^{+}$Channels}

\subsection{ATP Binding Cassette Subfamily C Member 9 (ABCC9)}

SUR2, encoded by ABCC9, can be spliced into the following two isoforms: SUR2A or SUR2B. SUR2A is mostly co-assembled with Kir6.2 and is expressed in cardiac tissues and skeletal muscles [102]. SUR2B is more often co-assembled with Kir6.1 and is expressed in several tissues, including vascular smooth muscle cells [69]. SUR2B/Kir6.1 are expressed in hPASMCs [103], where they are inhibited by PKC [104].

SUR2B/Kir6.1 are also expressed in endothelial cells from the bovine aorta, guinea pig coronary artery, and human coronary artery $[105,106]$.

SUR2A/Kir6.1 are mostly expressed in the heart, where they are well-known to be cardioprotective [107].

$A B C C 9$ mutations are the major genetic cause of Cantu Syndrome. Cantu Syndrome is characterized by congenital hypertrichosis, osteochondroplasia, and cardiac defects, such as cardiomegaly, dilated vasculature, tortuous vasculature, and pericardial effusion. Interestingly, some patients have also developed PH [108,109]. To date, 12 different mutations in ABCC9 have been identified in Cantu Syndrome. Electrophysiological recordings have demonstrated that $A B C C 9$ mutations are gain-of-function mutations [108-112]. The primary opening of SUR2A/Kir6.1 leads to systemic vasorelaxation and hypotension, and the secondary opening of SUR2A/Kir6.1 leads to compensatory cardiac hypertrophy and hypercontractility [113].

The development of PH observed in Cantu Syndrome patients may be attributed to these cardiovascular disorders. Some patients who have developed LV hypertrophy may also be diagnosed with PAH due to LV disease [67].

A potential treatment for Cantu Syndrome patients with PH may be sulfonylurea receptor inhibitors, such as glibenclamide or mimoxidil. However precaution should be taken due to the potential side effect on SUR1 in the pancreas [108,109] and lung [79].

\subsection{KCNA5 (Voltage-Gated $\mathrm{K}^{+}$Channels 1.5: Kv1.5)}

KCNA5 encodes Kv1.5, and Kv channels are involved in the control of cell excitability contributing to the regulation of $\mathrm{Em} . \mathrm{Kv}$ channels are activated by membrane depolarization, and their opening regulates $\left[\mathrm{Ca}^{2+}\right]_{\mathrm{i}}$ through the inhibition of voltage-gated $\mathrm{Ca}^{2+}$ channels [114].

$\mathrm{Kv}$ channels are formed by an $\alpha$ pore subunit (Kv1-Kv12) composed of a voltage sensor domain (VSD) that detects changes in the transmembrane voltage, as well as a pore domain (PD). VSD and PD are comprised of six transmembrane domains. $\mathrm{Kv}$ channels also contain a $\beta$ subunit, and they form as homo- or heterotetramers comprised of four $\alpha$ subunits and four $\beta$ subunits (Figure 6). 

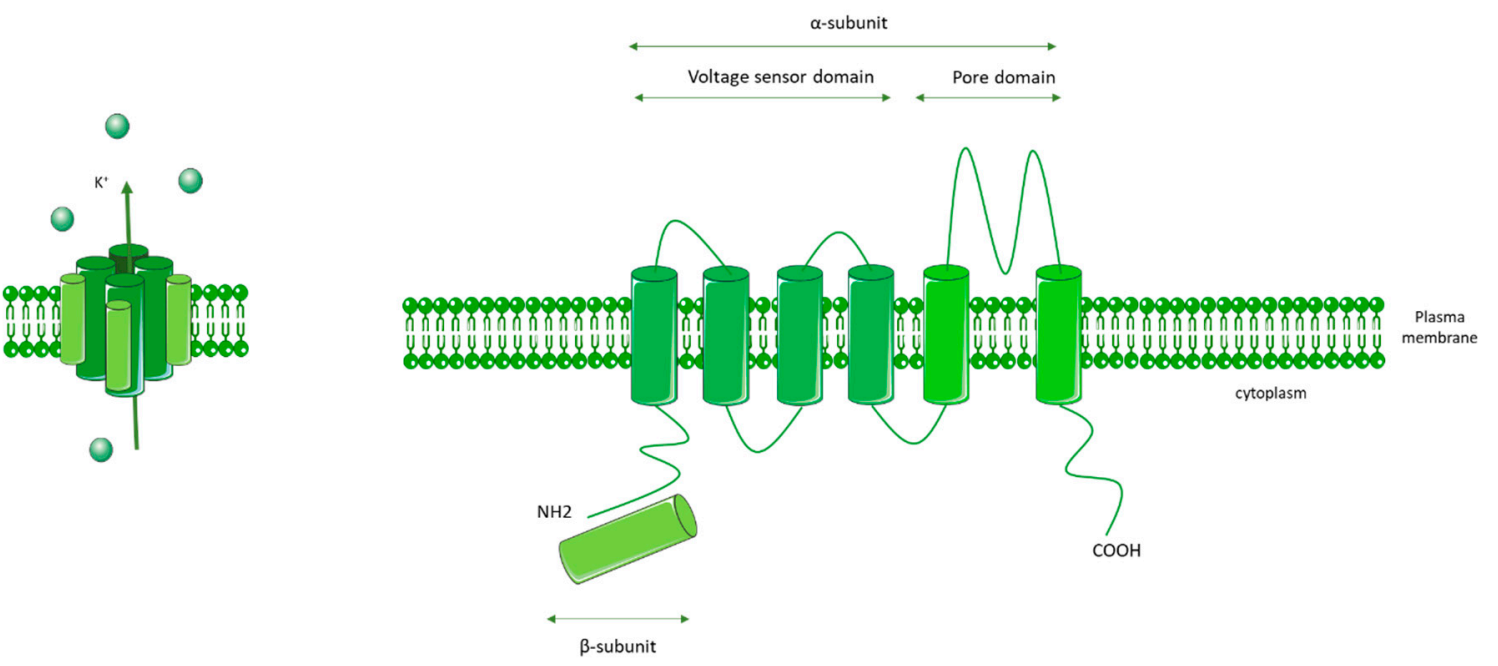

Figure 6. General molecular architecture of voltage-gated $\mathrm{K}^{+}$channels (Kv channels). Kv channels are comprised of a voltage sensor domain (VSD), which detects changes in the transmembrane voltage, and a pore domain (PD). The VSD and PD are comprised of six transmembrane domains. Kv channels are also comprised of a $\beta$ subunit. Kv channels form as homo- or heterotetramers composed of four $\alpha$ subunits and four $\beta$ subunits.

The putative role of KCNA5 single nucleotide polymorphisms (SNPs) in PAH has been investigated $[115,116]$. Indeed, Remillard et al. have identified 17 SNPs in iPAH patients and 12 SNPs have been identified in the $5^{\prime}$ untranslated region (UTR), 2 SNPs in the translated region of KCNA5, 2 SNPs in the $3^{\prime}$ UTR region, and 1 SNP in downstream KCNA5. Interestingly, the frequency of these two last SNPs in PAH patients with anorexigen history was significantly increased compared to in PAH patients without anorexigen history. These SNPs are localized in the promoter and translated regions of KCNA5, suggesting that they should alter the expression of Kv1.5 [116].

Four additional SNPs were identified in a cohort of PAH patients with systemic sclerosis. In this systemic sclerosis cohort, the KCNA5 rs10744676 variant was associated with protection against PAH [115]. The bioinformatics predictions suggest that this SNP should influence the transcription of KCNA5.

However, the functional consequences of all of these identified SNPs in KCNA5 have not yet been addressed.

In opposition, a meta-analysis study concluded that there is no relationship between SNPs in the KCNA5 gene and the development of PAH [117].

Kv1.5 is expressed in smooth muscle cells of several tissues and in hPASMCs. A hypoxic environment downregulates Kv1.5 in PASMCs, which is associated with membrane depolarization and an increase of intracellular $\mathrm{Ca}^{2+}$ influx $[15,118,119]$. In response to chronic hypoxia, HIF1- $\alpha$, which is the master transcription factor activated by hypoxia, mediates the downregulation of Kv1.5 expression. Bonnet et al. found, in spontaneous PH rats (fawn-hooded rats), that HIF1- $\alpha$ is overexpressed and the Kv1.5 expression/function are reduced. After the overexpression of a dominant negative HIF1- $\alpha$, they found that Kv1.5 expression/function were restored, demonstrating the implication of HIF1- $\alpha$ in the downregulation of Kv1.5. In the same study, they also demonstrated that HIF1- $\alpha$ was stabilized due to a pseudo-hypoxic state mediated by mitochondrial dysfunctions [120,121].

The reduced expression of Kv1.5 using antisense oligonucleotides or siRNA in PASMCs causes Em depolarization and increases the cytosolic $\mathrm{Ca}^{2+}$ concentration. The pharmacological inhibition of $\mathrm{Kv}$ channels by 4-Aminopurydine (4-AP) and correloide induces Em depolarization and stimulates PAMSC contraction $[119,122,123]$. Moreover, the PASMCs isolated from $k c n a 5^{-/-}$mice are depolarized compared to PASMCs isolated from WT mice [124]. Consequently, the hypoxic pulmonary vasoconstriction in the lungs and pulmonary arteries of $\mathrm{kcna5}^{-/-}$mice is reduced compared to that in WT mice [124]. 
Moreover, Archer et al., by using a specific antibody against Kv1.5 in PASMCs, showed that anti-Kv1.5 rapidly inhibited the outward- $\mathrm{K}^{+}$current and rapidly depolarized PASMCs [125].

Interestingly, in PASMCs overexpressing Kv1.5, acute hypoxia reduces outward $\mathrm{K}^{+}$currents and significantly depolarizes the Em potential, demonstrating that the $\mathrm{Kv} 1.5$ is a hypoxia-sensitive $\mathrm{Kv}$ channel in PASMCs $[15,126]$.

In PAH PASMCs, the decrease in Kv1.5 expression is associated with Em depolarization and an increase in $\left[\mathrm{Ca}^{2+}\right]_{i}[122,123,127]$. Mutations in BMPR2 are responsible for hPAH. A decrease in Kv1.5 mRNA expression is found in lungs from BMPR2-mutated patients. In hPASMCs treated with BMP2, the Kv1.5 expression and function are increased [128].

Conversely, the overexpression of hKv1.5 in rat PASMCs causes membrane hyperpolarization, enhancing apoptosis [129].

As mentioned earlier, the pathobiology of PAH includes an exaggerated expression of 5-HT, ET-1, and TXA2 [6,7]. As previously reviewed by Boucherat et al., numerous studies have demonstrated that Kv1.5 could be negatively regulated by the activation of phospholipase C (PLC) through the Gq family G-proteins, which include 5-HT, ET-1, and TXA2. In PASMCs, 5-HT signaling negatively regulates the trafficking and surface expression of Kv1.5 [120,130]. In PASMC, TXA2-induced Kv1.5 inhibition is partly mediated by the PKC $\zeta$ [120]. Since PLC inhibitor or PKC inhibitor application prevents the effects of 5-HT on the Kv1.5 current, ET-1 was also found to inhibit Kv1.5 channel currents [118]. Considering the contribution of Kv1.5 in Em of PASMCs, Kv1.5 inhibition induces the depolarization of PASMCs, enhancing pulmonary artery vasoconstriction, proliferation, and remodeling $[119,120,122,123,130]$. Moreover, some reports have demonstrated that serotonin-mediated PKC activation results in Kv1.5 inhibition $[119,120]$. Kv1.5 may also be regulated by endocytosis mediated by Src kinase [130]. The regulatory mechanisms of Kv1.5 are summarized in Figure 2.

Reduced Kv1.5 expressions and functions are observed in iPAH patients and in several experimental PH models [119,120,122,123,130]. Kv1.5 is also expressed in rat PAECs [131].

The Kv1.5 channel is expressed in human ventricular and atrium tissues [132,133]. In human and rat atria, Kv1.5 mediates an ultrarapid outward $\mathrm{K}^{+}$-current (IKur current), which contributes to atrial repolarization [133]. Consistent with the key role of Kv1.5 in the human atrium, the KCNA5-LOF mutation causes atrial fibrillation [134]. In ventricular myocytes from mice, Kv1.5 contributes to IKslow [135].

\section{Potential Therapeutic Targets}

\subsection{KCNK3}

As the loss of the KCNK3 function is a characteristic of iPAH and hPAH, KCNK3 may be a potential therapeutic target for treating PAH. We found that the in vivo long-term activation of KCNK3 by ONO-RS-082 ( $50 \mathrm{mg} / \mathrm{kg} /$ day; preventive treatment, day 0 to day 21 ) reduces the development of $\mathrm{PH}$ in the MCT-PH model. In contrast, in vivo short-term KCNK3 activation by ONO-RS-082 (curative treatment) fails to reduce $\mathrm{PH}$ symptoms, which is attributed to the complete loss of KCNK3 expression in MCT-PH rats at days 14 to 21. These findings reveal that in vivo KCNK3 activation may be effective at ameliorating PH when KCNK3 is expressed in Pas [30], suggesting that the pharmacological activation of KCNK3 may help treat PAH patients who have residual KCNK3 expression. Because the ONO-RS-082 compound is also a phospholipase A2 inhibitor, however, the use of ONO-RS-082 in humans may have deleterious side effects, further indicating the need for the development of more specific activators of KCNK3. Restoring KCNK3 pulmonary vascular expression by gene therapy may be an alternative strategy. In this way, and as suggested by Bohnen et al., forcing the expression of KCNK9 in pulmonary vasculature may be an additional strategy because the overexpression of KCNK9 may restore the function of KCNK3-mutated channels by co-assembly [24]. 


\subsection{KATP}

The major treatment for congenital hyperinsulinism and neonatal diabetes patients carrying $A B C C 8$ or KCNJ11 mutations is diazoxide (SUR1 activator) [136]. Diazoxide is one of the U.S. Food and Drug Administration-approved drugs for treating hyperinsulinemic hypoglycemia [137] and may be an interesting option for PAH treatment. Older findings have demonstrated that the acute activation of SUR1 by diazoxide strongly reduces mPAP in some PAH patients [138,139]. Moreover, our preliminary results demonstrated that the in vivo pharmacological activation of SUR1 by diazoxide attenuates the development of PH in MCT-PH rats [80]. However, several reports have indicated that hyperinsulinemic hypoglycemic infants treated with diazoxide develop PH [140-144]. Despite these limitations, our preliminary results suggest that the pharmacological activation of SUR1 should be considered in $\mathrm{PAH}$, indicating the need for more specific molecules for SUR1 activation in humans.

An alternative strategy may be to globally target KATP, as suggested by Zhu et al., who reported that treatment with iptakalim, a new KATP opener (SUR2/Kir6.1), attenuates PH induced by $\mathrm{CH}$ exposure [145]. Iptakalim reduces endothelin-induced proliferation in PASMCs [146] and endothelial dysfunction in rats [147]. Together, these results indicate that targeting KATP (SUR1 or SUR2) channels in PAH may also be a promising strategy for treating PAH.

\subsection{Kv1.5}

Because the Kv1.5 expression and function in pulmonary vasculature in PAH patients are severely impaired, an interesting strategy may be gene therapy. Pozeg et al. demonstrated that the in vivo gene transfer of KCNA5 attenuates PH induced by chronic hypoxia exposure in rats [148].

\section{Conclusions}

PAH remains an incurable disease, representing a major human and social burden. The identification of genetic variations in PAH helps the scientific community to better understand the pathophysiology of PAH and aids in the identification of new potential therapeutic targets. With the evolution of genome sequencing technology, LOF mutations have been identified in KCNK3 and in $A B C C 8$ in the last 7 years, suggesting that these molecules play a key role in the development of hPAH and $\mathrm{iPAH}$, which highlights their therapeutic potential for PAH. Regarding the downregulation of $\mathrm{K}^{+}$channels in $\mathrm{PAH}$, novel screening approaches, such as testing drugs, to restore the expression and function of KCNK3, SUR1, or Kv1.5 channels should be considered. Because KCNK3, SUR1, and Kv1.5 are ubiquitously expressed in human tissues, however, a specific pharmacological therapy targeting each of them should be carefully considered in preclinical development to avoid side effects.

Funding: Fabrice Antigny received funding from the National Funding Agency for Research (ANR-18-CE14-0023).

Conflicts of Interest: The authors declare that they have no competing interests.

\section{References}

1. Humbert, M.; Guignabert, C.; Bonnet, S.; Dorfmüller, P.; Klinger, J.R.; Nicolls, M.R.; Olschewski, A.J.; Pullamsetti, S.S.; Schermuly, R.T.; Stenmark, K.R.; et al. Pathology and pathobiology of pulmonary hypertension: State of the art and research perspectives. Eur. Respir. J. 2019, 53, 1801887. [CrossRef]

2. Simonneau, G.; Montani, D.; Celermajer, D.S.; Denton, C.P.; Gatzoulis, M.A.; Krowka, M.; Williams, P.G.; Souza, R. Haemodynamic definitions and updated clinical classification of pulmonary hypertension. Eur. Respir. J. 2019, 53, 1801913. [CrossRef]

3. Galiè, N.; Humbert, M.; Vachiéry, J.-L.; Gibbs, S.; Lang, I.M.; Torbicki, A.; Simonneau, G.; Peacock, A.; Noordegraaf, A.V.; Beghetti, M.; et al. 2015 ESC/ERS Guidelines for the diagnosis and treatment of pulmonary hypertension: The Joint Task Force for the Diagnosis and Treatment of Pulmonary Hypertension of the European Society of Cardiology (ESC) and the European Respiratory Society (ERS): Endorsed by: Association for European Paediatric and Congenital Cardiology (AEPC), International Society for Heart and Lung Transplantation (ISHLT). Eur. Heart J. 2015, 37, 67-119. [CrossRef] [PubMed] 
4. Hemnes, A.R.; Humbert, M. Pathobiology of pulmonary arterial hypertension: Understanding the roads less travelled. Eur. Respir. Rev. Off. J. Eur. Respir. Soc. 2017, 26. [CrossRef] [PubMed]

5. Humbert, M.; Lau, E.M.; Montani, D.; Jaïs, X.; Sitbon, O.; Simonneau, G. Advances in Therapeutic Interventions for Patients with Pulmonary Arterial Hypertension. Circulation 2014, 130, 2189-2208. [CrossRef] [PubMed]

6. Huertas, A.; Guignabert, C.; Barberà, J.A.; Bärtsch, P.; Bhattacharya, J.; Bhattacharya, S.; Bonsignore, M.R.; Dewachter, L.; Dinh-Xuan, A.T.; Dorfmüller, P.; et al. Pulmonary vascular endothelium: The orchestra conductor in respiratory diseases: Highlights from basic research to therapy. Eur. Respir. J. 2018, 51, 1700745. [CrossRef]

7. Humbert, M.; Morrell, N.W.; Archer, S.L.; Stenmark, K.R.; MacLean, M.R.; Lang, I.M.; Christman, B.W.; Weir, E.K.; Eickelberg, O.; Voelkel, N.F.; et al. Cellular and molecular pathobiology of pulmonary arterial hypertension. J. Am. Coll. Cardiol. 2004, 43, S13-S24. [CrossRef]

8. Machado, R.D.; Southgate, L.; Eichstaedt, C.A.; Aldred, M.A.; Austin, E.D.; Best, D.H.; Chung, W.K.; Benjamin, N.; Elliott, C.G.; Eyries, M.; et al. Pulmonary Arterial Hypertension: A Current Perspective on Established and Emerging Molecular Genetic Defects. Hum. Mutat. 2015, 36, 1113-1127. [CrossRef] [PubMed]

9. Eyries, M.; Montani, D.; Girerd, B.; Favrolt, N.; Riou, M.; Faivre, L.; Manaud, G.; Perros, F.; Grãf, S.; Morrell, N.W.; et al. Familial pulmonary arterial hypertension by KDR heterozygous loss of function. Eur. Respir. J. 2020, 55, 1902165. [CrossRef]

10. Kurdyukov, S.; Eccles, C.A.; Desai, A.A.; Gonzalez-Garay, M.L.; Yuan, J.X.-J.; Garcia, J.G.N.; Rafikova, O.; Rafikov, R. New cases of Glucose-6-Phosphate Dehydrogenase deficiency in Pulmonary Arterial Hypertension. PLoS ONE 2018, 13, e0203493. [CrossRef]

11. Southgate, L.; Machado, R.D.; Gräf, S.; Morrell, N.W. Molecular genetic framework underlying pulmonary arterial hypertension. Nat. Rev. Cardiol. 2019, 17, 85-95. [CrossRef] [PubMed]

12. Jenkinson, D.H. Potassium channels-Multiplicity and challenges. Br. J. Pharmacol. 2006, 147, S63-S71. [CrossRef] [PubMed]

13. Olschewski, A.; Veale, E.L.; Nagy, B.M.; Nagaraj, C.; Kwapiszewska, G.; Antigny, F.; Lambert, M.; Humbert, M.; Czirják, G.; Enyedi, P.; et al. TASK-1 (KCNK3) channels in the lung: From cell biology to clinical implications. Eur. Respir. J. 2017, 50, 1700754. [CrossRef] [PubMed]

14. Mouratoglou, S.A.; Giannakoulas, G.; Deftereos, S.G.; Giannopoulos, G.; Angelidis, C.; Cleman, M.W.; Vassilikos, V.P. Intra-and Intercellular Calcium Handling in Pulmonary Arterial Hypertension. Med. Chem. 2016, 12, 162-169. [CrossRef] [PubMed]

15. Moudgil, R.; Michelakis, E.D.; Archer, S.L. The Role of $\mathrm{K}^{+}$Channels in Determining Pulmonary Vascular Tone, Oxygen Sensing, Cell Proliferation, and Apoptosis: Implications in Hypoxic Pulmonary Vasoconstriction and Pulmonary Arterial Hypertension. Microcirculation 2006, 13, 615-632. [CrossRef]

16. Gardener, M.J.; Johnson, I.T.; Burnham, M.P.; Edwards, G.; Heagerty, A.M.; Weston, A.H. Functional evidence of a role for two-pore domain potassium channels in rat mesenteric and pulmonary arteries. Br. J. Pharmacol. 2004, 142, 192-202. [CrossRef]

17. Pandit, L.M.; Lloyd, E.E.; Reynolds, J.O.; Lawrence, W.S.; Reynolds, C.; Wehrens, X.H.T.; Bryan, R.M. TWIK-2 channel deficiency leads to pulmonary hypertension through a rho-kinase-mediated process. Hypertension 2014, 64, 1260-1265. [CrossRef]

18. Lambert, M.; Capuano, V.; Olschewski, A.; Sabourin, J.; Nagaraj, C.; Girerd, B.; Weatherald, J.; Humbert, M.; Antigny, F. Ion Channels in Pulmonary Hypertension: A Therapeutic Interest? Int. J. Mol. Sci. 2018, 19, 3162. [CrossRef]

19. Czirják, G.; Enyedi, P. Formation of Functional Heterodimers between the TASK-1 and TASK-3 Two-pore Domain Potassium Channel Subunits. J. Biol. Chem. 2002, 277, 5426-5432. [CrossRef]

20. Lambert, M.; Capuano, V.; Boet, A.; Tesson, L.; Bertero, T.; Nakhleh, M.K.; Remy, S.; Anegon, I.; Péchoux, C.; Hautefort, A.; et al. Characterization of Kcnk3-Mutated Rat, a Novel Model of Pulmonary Hypertension. Circ. Res. 2019, 125, 678-695. [CrossRef]

21. Putzke, C.; Wemhöner, K.; Sachse, F.B.; Rinné, S.; Schlichthörl, G.; Li, X.T.; Jaé, L.; Eckhardt, I.; Wischmeyer, E.; Wulf, H.; et al. The acid-sensitive potassium channel TASK-1 in rat cardiac muscle. Cardiovasc. Res. 2007, 75, 59-68. [CrossRef] [PubMed] 
22. Streit, A.K.; Netter, M.F.; Kempf, F.; Walecki, M.; Rinné, S.; Bollepalli, M.K.; Preisig-Müller, R.; Renigunta, V.; Daut, J.; Baukrowitz, T.; et al. A Specific Two-pore Domain Potassium Channel Blocker Defines the Structure of the TASK-1 Open Pore. J. Biol. Chem. 2011, 286, 13977-13984. [CrossRef] [PubMed]

23. Flaherty, D.P.; Simpson, D.S.; Miller, M.; Maki, B.E.; Zou, B.; Shi, J.; Wu, M.; McManus, O.B.; Aubé, J.; Li, M.; et al. Potent and selective inhibitors of the TASK-1 potassium channel through chemical optimization of a bis-amide scaffold. Bioorg. Med. Chem. Lett. 2014, 24, 3968-3973. [CrossRef] [PubMed]

24. Bohnen, M.S.; Roman-Campos, D.; Terrenoire, C.; Jnani, J.; Sampson, K.J.; Chung, W.K.; Kass, R.S. The Impact of Heterozygous KCNK3 Mutations Associated With Pulmonary Arterial Hypertension on Channel Function and Pharmacological Recovery. J. Am. Heart Assoc. 2017, 6. [CrossRef] [PubMed]

25. Kindler, C.H.; Yost, S.C.; Gray, A.T. Local Anesthetic Inhibition of Baseline Potassium Channels with Two Pore Domains in Tandem. Anesthesiology 1999, 90, 1092-1102. [CrossRef]

26. Berg, A.P.; Talley, E.M.; Manger, J.P.; Bayliss, D.A. Motoneurons Express Heteromeric TWIK-Related Acid-Sensitive $\mathrm{K}^{+}$(TASK) Channels Containing TASK-1 (KCNK3) and TASK-3 (KCNK9) Subunits. J. Neurosci. 2004, 24, 6693-6702. [CrossRef]

27. Veale, E.L.; Buswell, R.; Clarke, C.E.; Mathie, A. Identification of a region in the TASK3 two pore domain potassium channel that is critical for its blockade by methanandamide. Br. J. Pharmacol. 2007, 152, 778-786. [CrossRef]

28. Cotten, J.F. TASK-1 (KCNK3) and TASK-3 (KCNK9) Tandem Pore Potassium Channel Antagonists Stimulate Breathing in Isoflurane-Anesthetized Rats. Anesth. Analg. 2013, 116, 810-816. [CrossRef]

29. Cotten, J.F.; Keshavaprasad, B.; Laster, M.J.; Eger, E.I.; Yost, C.S. The Ventilatory Stimulant Doxapram Inhibits TASK Tandem Pore $\left(\mathrm{K}_{2 \mathrm{P}}\right)$ Potassium Channel Function but Does Not Affect Minimum Alveolar Anesthetic Concentration. Anesth. Analg. 2006, 102, 779-785. [CrossRef]

30. Antigny, F.; Hautefort, A.; Meloche, J.; Belacel-Ouari, M.; Manoury, B.; Rucker-Martin, C.; Péchoux, C.; Potus, F.; Nadeau, V.; Tremblay, E.; et al. Potassium Channel Subfamily K Member 3 (KCNK3) Contributes to the Development of Pulmonary Arterial Hypertension. Circulation 2016, 133, 1371-1385. [CrossRef]

31. Gurney, A.M.; Osipenko, O.N.; Macmillan, D.; McFarlane, K.M.; Tate, R.J.; Kempsill, F.E.J. Two-Pore Domain K Channel, TASK-1, in Pulmonary Artery Smooth Muscle Cells. Circ. Res. 2003, 93, 957-964. [CrossRef] [PubMed]

32. Czirják, G.; Enyedi, P. TASK-3 Dominates the Background Potassium Conductance in Rat Adrenal Glomerulosa Cells. Mol. Endocrinol. 2002, 16, 621-629. [CrossRef] [PubMed]

33. Olschewski, A.; Li, Y.; Tang, B.; Hanze, J.; Eul, B.; Bohle, R.M.; Wilhelm, J.; Morty, R.E.; Brau, M.E.; Weir, E.K.; et al. Impact of TASK-1 in Human Pulmonary Artery Smooth Muscle Cells. Circ. Res. 2006, 98, 1072-1080. [CrossRef] [PubMed]

34. Talley, E.M.; Lei, Q.; Sirois, J.E.; Bayliss, D.A. TASK-1, a Two-Pore Domain $\mathrm{K}^{+}$Channel, Is Modulated by Multiple Neurotransmitters in Motoneurons. Neuron 2000, 25, 399-410. [CrossRef]

35. Tang, B.; Li, Y.; Nagaraj, C.; Morty, R.E.; Gabor, S.; Stacher, E.; Voswinckel, R.; Weissmann, N.; Leithner, K.; Olschewski, H.; et al. Endothelin-1 Inhibits Background Two-Pore Domain Channel TASK-1 in Primary Human Pulmonary Artery Smooth Muscle Cells. Am. J. Respir. Cell Mol. Biol. 2009, 41, 476-483. [CrossRef]

36. Czirják, G.; Petheő, G.L.; Spät, A.; Enyedi, P. Inhibition of TASK-1 potassium channel by phospholipase C. Am. J. Physiol.-Cell Physiol. 2001, 281, C700-C708. [CrossRef]

37. Lopes, C.M.B.; Rohacs, T.; Czirják, G.; Ballac, T.; Enyedi, P.; Logothetis, D.E. PIP 2 hydrolysis underlies agonist-induced inhibition and regulates voltage gating of two-pore domain $\mathrm{K}^{+}$channels. J. Physiol. 2005, 564, 117-129. [CrossRef]

38. Wilke, B.U.; Lindner, M.; Greifenberg, L.; Albus, A.; Kronimus, Y.; Bünemann, M.; Leitner, M.G.; Oliver, D. Diacylglycerol mediates regulation of TASK potassium channels by Gq-coupled receptors. Nat. Commun. 2014, 5, 5540. [CrossRef]

39. Seyler, C.; Duthil-Straub, E.; Zitron, E.; Gierten, J.; Scholz, E.P.; Fink, R.H.A.; Karle, C.A.; Becker, R.; Katus, H.A.; Thomas, D. TASK1 $\left(\mathrm{K}_{2 \mathrm{P}} 3.1\right) \mathrm{K}^{+}$channel inhibition by endothelin-1 is mediated through Rho kinase-dependent phosphorylation. Br. J. Pharmacol. 2012, 165, 1467-1475. [CrossRef]

40. Toyoda, H.; Saito, M.; Okazawa, M.; Hirao, K.; Sato, H.; Abe, H.; Takada, K.; Funabiki, K.; Takada, M.; Kaneko, T.; et al. Protein Kinase G Dynamically Modulates TASK1-Mediated Leak K ${ }^{+}$Currents in Cholinergic Neurons of the Basal Forebrain. J. Neurosci. 2010, 30, 5677-5689. [CrossRef] 
41. Nagaraj, C.; Tang, B.; Bálint, Z.; Wygrecka, M.; Hrzenjak, A.; Kwapiszewska, G.; Stacher, E.; Lindenmann, J.; Weir, E.K.; Olschewski, H.; et al. Src tyrosine kinase is crucial for potassium channel function in human pulmonary arteries. Eur. Respir. J. 2013, 41, 85-95. [CrossRef] [PubMed]

42. Weatherald, J.; Chaumais, M.-C.; Savale, L.; Jaïs, X.; Seferian, A.; Canuet, M.; Bouvaist, H.; Magro, P.; Bergeron, A.; Guignabert, C.; et al. Long-term outcomes of dasatinib-induced pulmonary arterial hypertension: A population-based study. Eur. Respir. J. 2017, 50, 1700217. [CrossRef] [PubMed]

43. Antigny, F.; Mercier, O.; Humbert, M.; Sabourin, J. Excitation-contraction coupling and relaxation alteration in right ventricular remodelling caused by pulmonary arterial hypertension. Arch. Cardiovasc. Dis. 2020, 113, 70-84. [CrossRef] [PubMed]

44. Manoury, B.; Lamalle, C.; Oliveira, R.; Reid, J.; Gurney, A.M. Contractile and electrophysiological properties of pulmonary artery smooth muscle are not altered in TASK-1 knockout mice. J. Physiol. 2011, 589, 3231-3246. [CrossRef] [PubMed]

45. Enyedi, P.; Czirják, G. Molecular Background of Leak K ${ }^{+}$Currents: Two-Pore Domain Potassium Channels. Physiol. Rev. 2010, 90, 559-605. [CrossRef]

46. Lambert, M.; Boet, A.; Rucker-Martin, C.; Mendes-Ferreira, P.; Capuano, V.; Hatem, S.; Adão, R.; Brás-Silva, C.; Hautefort, A.; Michel, J.-B.; et al. Loss of KCNK3 is a hallmark of RV hypertrophy/dysfunction associated with pulmonary hypertension. Cardiovasc. Res. 2018, 114, 880-893. [CrossRef]

47. Schmidt, C.; Wiedmann, F.; Voigt, N.; Zhou, X.-B.; Heijman, J.; Lang, S.; Albert, V.; Kallenberger, S.; Ruhparwar, A.; Szabo, G.; et al. Upregulation of $\mathrm{K}_{2 \mathrm{P}} 3.1 \mathrm{~K}^{+}$Current Causes Action Potential Shortening in Patients With Chronic Atrial Fibrillation. Circulation 2015, 132, 82-92. [CrossRef]

48. Chai, S.; Wan, X.; Nassal, D.M.; Liu, H.; Moravec, C.S.; Ramirez-Navarro, A.; Deschênes, I. Contribution of two-pore $\mathrm{K}^{+}$channels to cardiac ventricular action potential revealed using human iPSC-derived cardiomyocytes. Am. J. Physiol.-Heart Circ. Physiol. 2017, 312, H1144-H1153. [CrossRef]

49. Rottlaender, D.; Motloch, L.J.; Schmidt, D.; Reda, S.; Larbig, R.; Wolny, M.; Dumitrescu, D.; Rosenkranz, S.; Erdmann, E.; Hoppe, U.C. Clinical Impact of Atrial Fibrillation in Patients with Pulmonary Hypertension. PLoS ONE 2012, 7, e33902. [CrossRef]

50. Ma, L.; Roman-Campos, D.; Austin, E.D.; Eyries, M.; Sampson, K.S.; Soubrier, F.; Germain, M.; Tregouet, D.-A.; Borczuk, A.; Rosenzweig, E.B.; et al. A novel channelopathy in pulmonary arterial hypertension. N. Engl. J. Med. 2013, 369, 351-361. [CrossRef]

51. Navas Tejedor, P.; Tenorio Castaño, J.; Palomino Doza, J.; Arias Lajara, P.; Gordo Trujillo, G.; López Meseguer, M.; Román Broto, A.; Lapunzina, P.; Escribano Subías, P. An homozygous mutation in KCNK3 is associated with an aggressive form of hereditary pulmonary arterial hypertension. Clin. Genet. 2016, 91, 453-457. [CrossRef]

52. Best, D.H.; Sumner, K.L.; Smith, B.P.; Damjanovich-Colmenares, K.; Nakayama, I.; Brown, L.M.; Ha, Y.; Paul, E.; Morris, A.; Jama, M.A.; et al. EIF2AK4 Mutations in Patients Diagnosed with Pulmonary Arterial Hypertension. Chest 2017, 151, 821-828. [CrossRef]

53. Zhang, H.-S.; Liu, Q.; Piao, C.-M.; Zhu, Y.; Li, Q.-Q.; Du, J.; Gu, H. Genotypes and Phenotypes of Chinese Pediatric Patients With Idiopathic and Heritable Pulmonary Arterial Hypertension-A Single-Center Study. Can. J. Cardiol. 2019, 35, 1851-1856. [CrossRef] [PubMed]

54. Haarman, M.G.; Kerstjens-Frederikse, W.S.; Vissia-Kazemier, T.R.; Breeman, K.T.N.; Timens, W.; Vos, Y.J.; Roofthooft, M.T.R.; Hillege, H.L.; Berger, R.M.F. The Genetic Epidemiology of Pediatric Pulmonary Arterial Hypertension. J. Pediatr. 2020. [CrossRef] [PubMed]

55. Higasa, K.; Ogawa, A.; Terao, C.; Shimizu, M.; Kosugi, S.; Yamada, R.; Date, H.; Matsubara, H.; Matsuda, F. A burden of rare variants in BMPR2 and KCNK3 contributes to a risk of familial pulmonary arterial hypertension. BMC Pulm. Med. 2017, 17, 57. [CrossRef] [PubMed]

56. Evans, J.D.W.; Girerd, B.; Montani, D.; Wang, X.-J.; Galié, N.; Austin, E.D.; Elliott, G.; Asano, K.; Grunig, E.; Yan, Y.; et al. BMPR2 mutations and survival in pulmonary arterial hypertension: An individual participant data meta-analysis. Lancet Respir. Med. 2016, 4, 129-137. [CrossRef]

57. Cunningham, K.P.; Holden, R.G.; Escribano-Subias, P.M.; Cogolludo, Á.; Veale, E.L.; Mathie, A. Characterization and regulation of wild-type and mutant TASK-1 two pore domain potassium channels indicated in pulmonary arterial hypertension. J. Physiol. 2019, 597, 1087-1101. [CrossRef] [PubMed] 
58. US Patent for Method of Treating a Condition Associated with Phosphorylation of TASK-1 Patent (Patent \# 8,097,650 Issued 17 January 2012)—Justia Patents Search. Available online: https://patents.justia.com/patent/ 8097650 (accessed on 22 May 2020).

59. Kitagawa, M.G.; Reynolds, J.O.; Wehrens, X.H.T.; Bryan, R.M.J.; Pandit, L.M. Hemodynamic and Pathologic Characterization of the TASK-1 ${ }^{-/-}$Mouse Does Not Demonstrate Pulmonary Hypertension. Front. Med. 2017, 4, 177. [CrossRef]

60. Anandharajan, R.; Eric, A.; Harikrishna, T.; Ling, Y.; Gladson, M.; Christy, M.; Sheila, S.; Tom, B.; Santhi, G.; Taylor, S.; et al. Abstract 16143: Inflammation Triggers the Onset of Hereditary Pulmonary Arterial Hypertension in Kcnk3-/- Animals. Circulation 2019, 140, A16143. [CrossRef]

61. Hautefort, A.; Mendes-Ferreira, P.; Sabourin, J.; Manaud, G.; Bertero, T.; Rücker-Martin, C.; Riou, M.; Adão, R.; Manoury, B.; Lambert, M.; et al. Bmpr2 Mutant Rats Develop Pulmonary and Cardiac Characteristics of Pulmonary Arterial Hypertension. Circulation 2019, 139, 932-948. [CrossRef]

62. Han, L.; Song, N.; Hu, X.; Zhu, A.; Wei, X.; Liu, J.; Yuan, S.; Mao, W.; Chen, X. Inhibition of RELM- $\beta$ prevents hypoxia-induced overproliferation of human pulmonary artery smooth muscle cells by reversing PLC-mediated KCNK3 decline. Life Sci. 2020, 246, 117419. [CrossRef] [PubMed]

63. Angelini, D.J.; Su, Q.; Yamaji-Kegan, K.; Fan, C.; Teng, X.; Hassoun, P.M.; Yang, S.C.; Champion, H.C.; Tuder, R.M.; Johns, R.A. Resistin-Like Molecule- $\beta$ in Scleroderma-Associated Pulmonary Hypertension. Am. J. Respir. Cell Mol. Biol. 2009, 41, 553-561. [CrossRef] [PubMed]

64. Aittoniemi, J.; Fotinou, C.; Craig, T.J.; De Wet, H.; Proks, P.; Ashcroft, F.M. SUR1: A unique ATP-binding cassette protein that functions as an ion channel regulator. Philos. Trans. R. Soc. B Biol. Sci. 2009, 364, $257-267$. [CrossRef] [PubMed]

65. Lee, K.P.K.; Chen, J.; MacKinnon, R. Molecular structure of human KATP in complex with ATP and ADP. eLife 2017, 6, e32481. [CrossRef]

66. Gribble, F.M.; Ashfield, R.; Ammala, C.; Ashcroft, F.M. Properties of cloned ATP-sensitive $\mathrm{K}^{+}$currents expressed in Xenopus oocytes. J. Physiol. 1997, 498, 87-98. [CrossRef]

67. McClenaghan, C.; Woo, K.V.; Nichols, C.G. Pulmonary Hypertension and ATP-Sensitive Potassium Channels. Hypertension 2019, 74, 14-22. [CrossRef]

68. Nichols, C.G. KATP channels as molecular sensors of cellular metabolism. Nature 2006, 440, 470-476. [CrossRef]

69. Foster, M.N.; Coetzee, W.A. KATP Channels in the Cardiovascular System. Physiol. Rev. 2016, 96, 177-252. [CrossRef]

70. Gribble, F.M.; Reimann, F. Sulphonylurea action revisited: The post-cloning era. Diabetologia 2003, 46, 875-891. [CrossRef]

71. Rorsman, P.; Eliasson, L.; Kanno, T.; Zhang, Q.; Göpel, S.O. Electrophysiology of pancreatic $\beta$-cells in intact mouse islets of Langerhans. Prog. Biophys. Mol. Biol. 2011, 107, 224-235. [CrossRef]

72. Prost, A.-L.; Bloc, A.; Hussy, N.; Dérand, R.; Vivaudou, M.B. Zinc is both an intracellular and extracellular regulator of KATP channel function. J. Physiol. 2004, 559, 157-167. [CrossRef] [PubMed]

73. Patel, S.; Fedinec, A.L.; Liu, J.; Weiss, M.A.; Pourcyrous, M.; Harsono, M.; Parfenova, H.; Leffler, C.W. $\mathrm{H}_{2} \mathrm{~S}$ mediates the vasodilator effect of endothelin-1 in the cerebral circulation. Am. J. Physiol.-Heart Circ. Physiol. 2018, 315, H1759-H1764. [CrossRef] [PubMed]

74. Thorneloe, K.S.; Maruyama, Y.; Malcolm, A.T.; Light, P.E.; Walsh, M.P.; Cole, W.C. Protein kinase C modulation of recombinant ATP-sensitive $\mathrm{K}^{+}$channels composed of Kir6.1 and/or Kir6.2 expressed with SUR2B. J. Physiol. 2002, 541, 65-80. [CrossRef] [PubMed]

75. Hayabuchi, Y.; Davies, N.W.; Standen, N.B. Angiotensin II inhibits rat arterial KATP channels by inhibiting steady-state protein kinase A activity and activating protein kinase Ce. J. Physiol. 2001, 530, 193-205. [CrossRef]

76. Tykocki, N.R.; Boerman, E.M.; Jackson, W.F. Smooth Muscle Ion Channels and Regulation of Vascular Tone in Resistance Arteries and Arterioles. Compr. Physiol. 2017, 7, 485-581. [CrossRef] [PubMed]

77. Zhang, Q.; Li, C.; Zhang, T.; Ge, Y.; Han, X.; Sun, S.; Ding, J.; Lu, M.; Hu, G. Deletion of Kir6.2/SUR1 potassium channels rescues diminishing of DA neurons via decreasing iron accumulation in PD. Mol. Cell. Neurosci. 2018, 92, 164-176. [CrossRef]

78. Lefer, D.J.; Nichols, C.G.; Coetzee, W.A. Sulfonylurea Receptor 1 Subunits of ATP-Sensitive Potassium Channels and Myocardial Ischemia/Reperfusion Injury. Trends Cardiovasc. Med. 2009, 19, 61-67. [CrossRef] 
79. Bohnen, M.S.; Ma, L.; Zhu, N.; Qi, H.; McClenaghan, C.; Gonzaga-Jauregui, C.; Dewey, F.E.; Overton, J.D.; Reid, J.G.; Shuldiner, A.R.; et al. Loss-of-Function ABCC8 Mutations in Pulmonary Arterial Hypertension. Circ. Genom. Precis. Med. 2018, 11. [CrossRef]

80. Le Ribeuz, H.; Boët, A.; Lambert, M.; Chung, W.K.; Montani, D.; Humbert, M.; Antigny, F. Sur1/kir6.2 Potassium Channel a New Actor Involved in Pulmonary Arterial Hypertension. Circulation 2019, 140, A10804. [CrossRef]

81. Kurland, D.B.; Gerzanich, V.; Karimy, J.K.; Woo, S.K.; Vennekens, R.; Freichel, M.; Nilius, B.; Bryan, J.; Simard, J.M. The Sur1-Trpm4 channel regulates NOS2 transcription in TLR4-activated microglia. J. Neuroinflamm. 2016, 13, 130. [CrossRef]

82. Yang, X.-R.; Lin, M.-J.; McIntosh, L.S.; Sham, J.S.K. Functional expression of transient receptor potential melastatin- and vanilloid-related channels in pulmonary arterial and aortic smooth muscle. Am. J. Physiol.-Lung Cell. Mol. Physiol. 2006, 290, L1267-L1276. [CrossRef] [PubMed]

83. Earley, S.; Waldron, B.J.; Brayden, J.E. Critical Role for Transient Receptor Potential Channel TRPM4 in Myogenic Constriction of Cerebral Arteries. Circ. Res. 2004, 95, 922-929. [CrossRef] [PubMed]

84. Blödow, A.; Begandt, D.; Bader, A.; Becker, A.; Burghard, A.; Kühne, D.; Kral, A.; Ngezahayo, A. ATP-sensitive $\mathrm{K}^{+}$channels (Kir6.1/SUR1) regulate gap junctional coupling in cochlear-supporting cells. Pflügers Arch.-Eur. J. Physiol. 2016, 468, 1215-1222. [CrossRef]

85. Soundarapandian, M.M.; Wu, D.; Zhong, X.; Petralia, R.S.; Peng, L.; Tu, W.; Lu, Y. Expression of functional Kir6.1 channels regulates glutamate release at CA3 synapses in generation of epileptic form of seizures. J. Neurochem. 2007, 103, 1982-1988. [CrossRef] [PubMed]

86. Dart, C.; Standen, N.B. Activation of ATP-dependent $\mathrm{K}^{+}$channels by hypoxia in smooth muscle cells isolated from the pig coronary artery. J. Physiol. 1995, 483, 29-39. [CrossRef]

87. Quayle, J.M.; Turner, M.R.; Burrell, H.E.; Kamishima, T. Effects of hypoxia, anoxia, and metabolic inhibitors on KATP channels in rat femoral artery myocytes. Am. J. Physiol.-Heart Circ. Physiol. 2006, 291, H71-H80. [CrossRef]

88. Nichols, C.G. ATP-sensitive Potassium Currents in Heart Disease and Cardioprotection. Card. Electrophysiol. Clin. 2016, 8, 323-335. [CrossRef]

89. Fedorov, V.V.; Glukhov, A.V.; Ambrosi, C.M.; Kostecki, G.; Chang, R.; Janks, D.; Schuessler, R.B.; Moazami, N.; Nichols, C.G.; Efimov, I.R. Effects of KATP channel openers diazoxide and pinacidil in coronary-perfused atria and ventricles from failing and non-failing human hearts. J. Mol. Cell. Cardiol. 2011, 51, 215-225. [CrossRef]

90. Movahed, M.-R.; Hashemzadeh, M.; Jamal, M.M. The prevalence of pulmonary embolism and pulmonary hypertension in patients with type II diabetes mellitus. Chest 2005, 128, 3568-3571. [CrossRef]

91. Lang, I.M.; Palazzini, M. The burden of comorbidities in pulmonary arterial hypertension. Eur. Heart J. Suppl. 2019, 21, K21-K28. [CrossRef]

92. Abernethy, A.D.; Stackhouse, K.; Hart, S.; Devendra, G.; Bashore, T.M.; Dweik, R.; Krasuski, R.A. Impact of diabetes in patients with pulmonary hypertension. Pulm. Circ. 2015, 5, 117-123. [CrossRef] [PubMed]

93. Ashcroft, F.M.; Puljung, M.C.; Vedovato, N. Neonatal Diabetes and the KATP Channel: From Mutation to Therapy. Trends Endocrinol. Metab. 2017, 28, 377-387. [CrossRef] [PubMed]

94. Galcheva, S.; Demirbilek, H.; Al-Khawaga, S.; Hussain, K. The Genetic and Molecular Mechanisms of Congenital Hyperinsulinism. Front. Endocrinol. 2019, 10, 10. [CrossRef] [PubMed]

95. Seino, S.; Iwanaga, T.; Nagashima, K.; Miki, T. Diverse roles of K(ATP) channels learned from Kir6.2 genetically engineered mice. Diabetes 2000, 49, 311-318. [CrossRef]

96. Zingman, L.V.; Hodgson, D.M.; Bast, P.H.; Kane, G.C.; Perez-Terzic, C.; Gumina, R.J.; Pucar, D.; Bienengraeber, M.; Dzeja, P.P.; Miki, T.; et al. Kir6.2 is required for adaptation to stress. Proc. Natl. Acad. Sci. USA 2002, 99, 13278-13283. [CrossRef]

97. Yamada, S.; Kane, G.C.; Behfar, A.; Liu, X.-K.; Dyer, R.B.; Faustino, R.S.; Miki, T.; Seino, S.; Terzic, A. Protection conferred by myocardial ATP-sensitive $\mathrm{K}^{+}$channels in pressure overload-induced congestive heart failure revealed in KCNJ11 Kir6.2-null mutant. J. Physiol. 2006, 577, 1053-1065. [CrossRef]

98. Kane, G.C.; Behfar, A.; Dyer, R.B.; O'Cochlain, D.F.; Liu, X.-K.; Hodgson, D.M.; Reyes, S.; Miki, T.; Seino, S.; Terzic, A. KCNJ11 gene knockout of the Kir6.2 K ATP channel causes maladaptive remodeling and heart failure in hypertension. Hum. Mol. Genet. 2006, 15, 2285-2297. [CrossRef] 
99. Seghers, V.; Nakazaki, M.; DeMayo, F.J.; Aguilar-Bryan, L.; Bryan, J. Sur1Knockout Mice. J. Biol. Chem. 2000, 275, 9270-9277. [CrossRef]

100. Shiota, C.; Larsson, O.; Shelton, K.D.; Shiota, M.; Efanov, A.M.; Høy, M.; Lindner, J.; Kooptiwut, S.; Juntti-Berggren, L.; Gromada, J.; et al. Sulfonylurea Receptor Type 1 Knock-out Mice Have Intact Feeding-stimulated Insulin Secretion despite Marked Impairment in Their Response to Glucose. J. Biol. Chem. 2002, 277, 37176-37183. [CrossRef]

101. Melamed-Frank, M.; Terzic, A.; Carrasco, A.J.; Nevo, E.; Avivi, A.; Levy, A.P. Reciprocal regulation of expression of pore-forming KATP channel genes by hypoxia. Mol. Cell. Biochem. 2001, 225, 145-150. [CrossRef]

102. Yokoshiki, H.; Sunagawa, M.; Seki, T.; Sperelakis, N. ATP-sensitive $\mathrm{K}^{+}$channels in pancreatic, cardiac, and vascular smooth muscle cells. Am. J. Physiol.-Cell Content 1998, 274, C25-C37. [CrossRef] [PubMed]

103. Cui, Y.; Tran, S.; Tinker, A.; Clapp, L.H. The Molecular Composition of KATP Channels in Human Pulmonary Artery Smooth Muscle Cells and Their Modulation by Growth. Am. J. Respir. Cell Mol. Biol. 2002, 26, 135-143. [CrossRef] [PubMed]

104. Cole, W.C.; Malcolm, T.; Walsh, M.P.; Light, P.E. Inhibition by Protein Kinase C of the $\mathrm{K}_{\mathrm{NDP}}$ Subtype of Vascular Smooth Muscle ATP-Sensitive Potassium Channel. Circ. Res. 2000, 87, 112-117. [CrossRef] [PubMed]

105. Mehrke, G.; Pohl, U.; Daut, J. Effects of vasoactive agonists on the membrane potential of cultured bovine aortic and guinea-pig coronary endothelium. J. Physiol. 1991, 439, 277-299. [CrossRef]

106. Yoshida, H.; Feig, J.E.; Morrissey, A.; Ghiu, I.A.; Artman, M.; Coetzee, W.A. KATP channels of primary human coronary artery endothelial cells consist of a heteromultimeric complex of Kir6.1, Kir6.2, and SUR2B subunits. J. Mol. Cell. Cardiol. 2004, 37, 857-869. [CrossRef]

107. Stoller, D.A.; Fahrenbach, J.P.; Chalupský, K.; Tan, B.-H.; Aggarwal, N.; Metcalfe, J.; Hadhazy, M.; Shi, N.-Q.; Makielski, J.C.; McNally, E.M. Cardiomyocyte sulfonylurea receptor 2-KATP channel mediates cardioprotection and ST segment elevation. Am. J. Physiol.-Heart Circ. Physiol. 2010, 299, H1100-H1108. [CrossRef]

108. Harakalova, M.; Van Harssel, J.J.T.; Terhal, P.A.; Van Lieshout, S.; Duran, K.; Renkens, I.; Amor, D.J.; Wilson, L.C.; Kirk, E.P.; Turner, C.L.S.; et al. Dominant missense mutations in ABCC9 cause Cantú syndrome. Nat. Genet. 2012, 44, 793-796. [CrossRef]

109. Ma, A.; Gurnasinghani, S.; Kirk, E.P.; McClenaghan, C.; Singh, G.K.; Grange, D.K.; Pandit, C.; Zhu, Y.; Roscioli, T.; Elakis, G.; et al. Glibenclamide treatment in a Cantú syndrome patient with a pathogenic ABCC9 gain-of-function variant: Initial experience. Am. J. Med. Genet. Part A 2019, 179, 1585-1590. [CrossRef]

110. Park, J.Y.; Koo, S.H.; Jung, Y.J.; Lim, Y.-J.; Chung, M.L. A patient with Cantú syndrome associated with fatal bronchopulmonary dysplasia and pulmonary hypertension. Am. J. Med. Genet. Part A 2014, 164, 2118-2120. [CrossRef]

111. Kobayashi, D.; Cook, A.L.; Williams, D.A. Pulmonary hypertension secondary to partial pulmonary venous obstruction in a child with Cantu syndrome. Pediatr. Pulmonol. 2010, 45, 727-729. [CrossRef]

112. McClenaghan, C.; Hanson, A.; Sala-Rabanal, M.; Roessler, H.I.; Josifova, D.; Grange, D.K.; Van Haaften, G.; Nichols, C.G. Cantu syndrome-associated SUR2 (ABCC9) mutations in distinct structural domains result in KATP channel gain-of-function by differential mechanisms. J. Biol. Chem. 2018, 293, 2041-2052. [CrossRef] [PubMed]

113. Huang, Y.; McClenaghan, C.; Harter, T.M.; Hinman, K.; Halabi, C.M.; Matkovich, S.J.; Zhang, H.; Brown, G.S.; Mecham, R.P.; England, S.K.; et al. Cardiovascular consequences of KATP overactivity in Cantu syndrome. JCI Insight 2018, 3. [CrossRef] [PubMed]

114. Barros, F.; Pardo, L.A.; Dominguez, P.; Sierra, L.M.; De La Peña, P. New Structures and Gating of Voltage-Dependent Potassium (Kv) Channels and Their Relatives: A Multi-Domain and Dynamic Question. Int. J. Mol. Sci. 2019, 20, 248. [CrossRef] [PubMed]

115. Wipff, J.; Dieude, P.; Guedj, M.; Ruiz, B.; Riemekasten, G.; Cracowski, J.L.; Matucci-Cerinic, M.; Melchers, I.; Humbert, M.; Hachulla, E.; et al. Association of a KCNA5 gene polymorphism with systemic sclerosis-associated pulmonary arterial hypertension in the European Caucasian population. Arthritis Rheum. 2010, 62, 3093-3100. [CrossRef] [PubMed] 
116. Remillard, C.V.; Tigno, D.D.; Platoshyn, O.; Burg, E.D.; Brevnova, E.E.; Conger, D.; Nicholson, A.; Rana, B.K.; Channick, R.N.; Rubin, L.J.; et al. Function of Kv1.5 channels and genetic variations ofKCNA5in patients with idiopathic pulmonary arterial hypertension. Am. J. Physiol.-Cell Physiol. 2007, 292, C1837-C1853. [CrossRef]

117. Jiao, Y.-R.; Wang, W.; Lei, P.-C.; Jia, H.-P.; Dong, J.; Gou, Y.-Q.; Chen, C.-L.; Cao, J.; Wang, Y.-F.; Zhu, Y. 5-HTT, BMPR2, EDN1, ENG, KCNA5 gene polymorphisms and susceptibility to pulmonary arterial hypertension: A meta-analysis. Gene 2019, 680, 34-42. [CrossRef]

118. Yuan, X.-J. Voltage-Gated $\mathrm{K}^{+}$Currents Regulate Resting Membrane Potential and $\left[\mathrm{Ca}^{2+}\right]_{\mathrm{i}}$ in Pulmonary Arterial Myocytes. Circ. Res. 1995, 77, 370-378. [CrossRef]

119. Platoshyn, O.; Golovina, V.A.; Bailey, C.L.; Limsuwan, A.; Krick, S.; Juhaszova, M.; Seiden, J.E.; Rubin, L.J.; Yuan, J.X.-J. Sustained membrane depolarization and pulmonary artery smooth muscle cell proliferation. Am. J. Physiol. Physiol. 2000, 279, C1540-C1549. [CrossRef]

120. Boucherat, O.; Chabot, S.; Antigny, F.; Perros, F.; Provencher, S.; Bonnet, S. Potassium channels in pulmonary arterial hypertension. Eur. Respir. J. 2015, 46, 1167-1177. [CrossRef]

121. Bonnet, S.; Michelakis, E.D.; Porter, C.J.; Andrade -Navarro, M.A.; Thébaud, B.; Bonnet, S.; Haromy, A.; Harry, G.; Moudgil, R.; McMurtry, M.S.; et al. An Abnormal Mitochondrial-Hypoxia Inducible Factor-1 $\alpha-\mathrm{Kv}$ Channel Pathway Disrupts Oxygen Sensing and Triggers Pulmonary Arterial Hypertension in Fawn Hooded Rats: Similarities to human pulmonary arterial hypertension. Circulation 2006, 113, 2630-2641. [CrossRef]

122. Rao, J.N.; Platoshyn, O.; Li, L.; Guo, X.; Golovina, V.A.; Yuan, J.X.-J.; Wang, J.-Y. Activation of $\mathrm{K}^{+}$channels and increased migration of differentiated intestinal epithelial cells after wounding. Am. J. Physiol.-Cell Physiol. 2002, 282, C885-C898. [CrossRef] [PubMed]

123. Archer, S.L.; Wu, X.-C.; Thébaud, B.; Nsair, A.; Bonnet, S.; Tyrrell, B.; McMurtry, M.S.; Hashimoto, K.; Harry, G.; Michelakis, E.D. Preferential Expression and Function of Voltage-Gated, $\mathrm{O}^{2}$-Sensitive $\mathrm{K}^{+}$Channels in Resistance Pulmonary Arteries Explains Regional Heterogeneity in Hypoxic Pulmonary Vasoconstriction: Ionic diversity in smooth muscle cells. Circ. Res. 2004, 95, 308-318. [CrossRef] [PubMed]

124. Archer, S.L.; London, B.; Hampl, V.; Wu, X.; Nsair, A.; Puttagunta, L.; Hashimoto, K.; Waite, R.E.; Michelakis, E.D. Impairment of hypoxic pulmonary vasoconstriction in mice lacking the voltage-gated potassium channel Kv1. FASEB J. 2001, 15, 1801-1803. [CrossRef]

125. Archer, S.L.; Souil, E.; Dinh-Xuan, A.T.; Schremmer, B.; Mercier, J.C.; El Yaagoubi, A.; Nguyen-Huu, L.; Reeve, H.L.; Hampl, V. Molecular identification of the role of voltage-gated $\mathrm{K}^{+}$channels, Kv1.5 and Kv2.1, in hypoxic pulmonary vasoconstriction and control of resting membrane potential in rat pulmonary artery myocytes. J. Clin. Investig. 1998, 101, 2319-2330. [CrossRef] [PubMed]

126. Firth, A.L.; Platoshyn, O.; Brevnova, E.E.; Burg, E.D.; Powell, F.; Haddad, G.H.; Yuan, J.X.-J. Hypoxia Selectively Inhibits KCNA5 Channels in Pulmonary Artery Smooth Muscle Cells. Ann. N. Y. Acad. Sci. 2009, 1177, 101-111. [CrossRef] [PubMed]

127. Yuan, X.-J.; Wang, J.; Juhaszova, M.; Gaine, S.P.; Rubin, L.J. Attenuated $\mathrm{K}^{+}$channel gene transcription in primary pulmonary hypertension. Lancet 1998, 351, 726-727. [CrossRef]

128. Young, K.A.; Ivester, C.; West, J.; Carr, M.; Rodman, D.M. BMP signaling controls PASMC KV channel expression in vitro and in vivo. Am. J. Physiol.-Lung Cell. Mol. Physiol. 2006, 290, L841-L848. [CrossRef]

129. Brevnova, E.E.; Platoshyn, O.; Zhang, S.; Yuan, J.X.-J. Overexpression of human KCNA5 increases $\mathrm{I}_{\mathrm{K}(\mathrm{V})}$ and enhances apoptosis. Am. J. Physiol.-Cell Physiol. 2004, 287, C715-C722. [CrossRef]

130. Nesti, E.; Everill, B.; Morielli, A.D. Endocytosis as a Mechanism for Tyrosine Kinase-dependent Suppression of a Voltage-gated Potassium Channel. Mol. Biol. Cell 2004, 15, 4073-4088. [CrossRef]

131. Hogg, D.S.; McMurray, G.; Kozlowski, R.Z. Endothelial Cells Freshly Isolated from Small Pulmonary Arteries of the Rat Possess Multiple Distinct K+ Current Profiles. Lung 2002, 180, 203-214. [CrossRef]

132. Fedida, D.; Eldstrom, J.; Hesketh, J.C.; Lamorgese, M.; Castel, L.; Steele, D.F.; Van Wagoner, D.R. Kv1.5 Is an Important Component of Repolarizing $\mathrm{K}^{+}$Current in Canine Atrial Myocytes. Circ. Res. 2003, 93, 744-751. [CrossRef] [PubMed]

133. Jeevaratnam, K.; Chadda, K.R.; Huang, C.L.-H.; Camm, A.J. Cardiac Potassium Channels: Physiological Insights for Targeted Therapy. J. Cardiovasc. Pharmacol. Ther. 2018, 23, 119-129. [CrossRef] [PubMed]

134. Olson, T.M.; Alekseev, A.E.; Liu, X.K.; Park, S.; Zingman, L.V.; Bienengraeber, M.; Sattiraju, S.; Ballew, J.D.; Jahangir, A.; Terzic, A. Kv1.5 channelopathy due to KCNA5 loss-of-function mutation causes human atrial fibrillation. Hum. Mol. Genet. 2006, 15, 2185-2191. [CrossRef] [PubMed] 
135. London, B.; Guo, W.; Pan, X.-H.; Lee, J.S.; Shusterman, V.; Rocco, C.J.; Logothetis, D.A.; Nerbonne, J.M.; Hill, J.A. Targeted Replacement of Kv1.5 in the Mouse Leads to Loss of the 4-Aminopyridine-Sensitive Component of $\mathrm{I}_{\mathrm{K} \text {,slow }}$ and Resistance to Drug-Induced QT Prolongation. Circ. Res. 2001, 88, 940-946. [CrossRef] [PubMed]

136. Demirbilek, H.; Hussain, K. Congenital Hyperinsulinism: Diagnosis and Treatment Update. J. Clin. Res. Pediatr. Endocrinol. 2017, 9, 69-87. [CrossRef] [PubMed]

137. Galcheva, S.V.; Al-Khawaga, S.; Hussain, K. Diagnosis and management of hyperinsulinaemic hypoglycaemia. Best Pract. Res. Clin. Endocrinol. Metab. 2018, 32, 551-573. [CrossRef] [PubMed]

138. Chan, N.S.; McLay, J.; Kenmure, A.C. Reversibility of primary pulmonary hypertension during six years of treatment with oral diazoxide. Heart 1987, 57, 207-209. [CrossRef] [PubMed]

139. Klinke, W.P.; Gilbert, J.A.L. Diazoxide in Primary Pulmonary Hypertension. N. Engl. J. Med. 1980, 302, 91-92. [CrossRef]

140. Chen, S.C.; Dastamani, A.; Pintus, D.; Yau, D.; Aftab, S.; Bath, L.; Swinburne, C.; Hunter, L.; Giardini, A.; Christov, G.; et al. Diazoxide-induced pulmonary hypertension in hyperinsulinaemic hypoglycaemia: Recommendations from a multicentre study in the United Kingdom. Clin. Endocrinol. 2019, 91, 770-775. [CrossRef]

141. Kylat, R. Pulmonary hypertension occurring with diazoxide use in a preterm infant with hypoglycemia. Drug Healthc. Patient Saf. 2019, 11, 7-10. [CrossRef] [PubMed]

142. Nebesio, T.D.; Hoover, W.C.; Caldwell, R.L.; Nitu, M.E.; Eugster, E.A. Development of Pulmonary Hypertension in an Infant Treated with Diazoxide. J. Pediatr. Endocrinol. Metab. 2007, 20, 939-944. [CrossRef] [PubMed]

143. Timlin, M.R.; Black, A.B.; Delaney, H.M.; Matos, R.I.; Percival, C.S. Development of Pulmonary Hypertension During Treatment with Diazoxide: A Case Series and Literature Review. Pediatr. Cardiol. 2017, 38, 1247-1250. [CrossRef]

144. FDA. FDA Drug Safety Communication: FDA Warns about a Serious Lung Condition in Infants and Newborns Treated with Proglycem (Diazoxide); FDA: White Oak, MD, USA, 2019.

145. Zhu, R.; Bi, L.-Q.; Wu, S.-L.; Li, L.; Kong, H.; Xie, W.-P.; Wang, H.; Meng, Z.-L. Iptakalim attenuates hypoxia-induced pulmonary arterial hypertension in rats by endothelial function protection. Mol. Med. Rep. 2015, 12, 2945-2952. [CrossRef] [PubMed]

146. Zhu, Y.; Zhang, S.; Xie, W.; Li, Q.; Zhou, Y.; Wang, H. Iptakalim inhibited endothelin-1-induced proliferation of human pulmonary arterial smooth muscle cells through the activation of KATP channel. Vasc. Pharmacol. 2008, 48, 92-99. [CrossRef] [PubMed]

147. Wang, S.-Y.; Cui, W.-Y.; Wang, H. The new antihypertensive drug iptakalim activates ATP-sensitive potassium channels in the endothelium of resistance blood vessels. Acta Pharmacol. Sin. 2015, 36, 1444-1450. [CrossRef] [PubMed]

148. Pozeg, Z.I.; Michelakis, E.D.; McMurtry, M.S.; Thébaud, B.; Wu, X.-C.; Dyck, J.R.; Hashimoto, K.; Wang, S.; Moudgil, R.; Harry, G.; et al. In Vivo Gene Transfer of the $\mathrm{O}^{2}$-Sensitive Potassium Channel Kv1.5 Reduces Pulmonary Hypertension and Restores Hypoxic Pulmonary Vasoconstriction in Chronically Hypoxic Rats. Circualtion 2003, 107, 2037-2044. [CrossRef]

(C) 2020 by the authors. Licensee MDPI, Basel, Switzerland. This article is an open access article distributed under the terms and conditions of the Creative Commons Attribution (CC BY) license (http://creativecommons.org/licenses/by/4.0/). 